\title{
En bloc transurethral resection of bladder tumors: A review of current techniques
}

Stefanie M. Croghan ${ }^{1}$; Niall Compton ${ }^{1}$; Rustom P. Manecksha²; Ivor M. Cullen";

Pádraig J. Daly ${ }^{1}$

${ }^{1}$ Department of Urology, University Hospital Waterford, Waterford, Ireland; ${ }^{2}$ Department of Urology, St. James's Hospital Dublin and Department of Surgery, Trinity College Dublin, Ireland

Cite as: Croghan SM, Compton N, Manecksha RP, et al. En bloc transurethral resection of bladder tumours (ERBT): A review of current techniques. Can Urol Assoc J 2021 Deceber 21; Epub ahead of print. http://dx.doi.org/10.5489/cuaj.7539

Published online December 21, 2021

Corresponding author: Dr. Stefanie M. Croghan, Department of Urology, University Hospital Waterford, Waterford, Ireland; stefaniecroghan@rcsi.com

$* * *$

\section{Abstract}

Introduction: Growing interest surrounds the concept of en bloc transurethral resection of bladder tumors (ERBT). Theoretical advantages include improved adherence to oncological principles and potential yield of superior pathological specimens. Multiple ERBT methods exist. This review summarizes the current evidence regarding application of differing techniques and technologies to ERBT.

Methods: A systematic review of MEDLINE/EMBASE/Scopus databases was performed, using terms "en bloc," "ERBT," "bladder," and "urinary bladder neoplasm." Template-based data extraction included technique of ERBT, feasibility, tumor size, activation of obturator nerve reflex, operative complications, detrusor muscle sampling rate, and recurrence data. Results: Multiple approaches to ERBT have evolved, using a variety of energy sources. The feasibility of electrocautery, laser, combined waterjet/electrocautery, and polypectomy snare techniques have been confirmed in achieving ERBT. ERBT appears safe, with a low complication rate. The use of laser energy sources reduces the risk of activating the obturator nerve reflex during lateral wall resections. Otherwise, no energy source is unequivocally superior in achieving ERBT. The rate of detrusor muscle sampling is high with use of ERBT and appears superior to that achieved with conventional TURBT (cTURBT) in multiple comparative studies. A limited number of largely non-randomized trials assess bladder tumor recurrence; current evidence suggests this is similar between ERBT and cTURBT groups.

Conclusions: En bloc resection of bladder tumors using a variety of technologies is feasible and safe, with a high detrusor muscle sampling rate. Further research is required to determine whether rates of residual disease or recurrence can be reduced with ERBT vs. cTURBT. 


\section{Introduction}

Bladder cancer is the $12^{\text {th }}$ most common malignancy worldwide. ${ }^{1}$ The cornerstone of accurate diagnosis and local staging is a well-performed transurethral resection of bladder tumour (TURBT), which additionally serves as the primary treatment strategy for non-muscle invasive disease. The conventional approach to TURBT (cTURBT) involves resection of the tumour in layers, resulting in multiple tumour fragments that are evacuated for histological analysis. $^{2}$ Such a technique may promote 'tumour scatter.' This is a longstanding concern in urologic oncology, since the reimplantation theory of malignant urothelial cells was proposed by Albarran and Imbert in 1903. ${ }^{3}$ Efforts to remove bladder tumours whole have been described as far back as 1980 , with a polypectomy snare. ${ }^{4}$ The current concept of transurethral energy-assisted resection of a bladder tumour as a single intact specimen with the inclusion of lamina propria $+/$ - muscularis propria fibres, was described in $2000 .^{5}$ This technique adheres to the oncological principle of excising malignant tissue 'en bloc' with a negative resection margin. ${ }^{6}$ In addition, en bloc TURBT (ERBT) allows accurate orientation of the extracted tumour specimen, ${ }^{7}$ and may be associated with greater rates of detrusor muscle sampling than alternative techniques, ${ }^{8}$ thus facilitating pathological staging. ${ }^{9}$

A variety of en bloc bladder tumour resection (ERBT) techniques have been described. This purpose of this review is to summarise the available modalities of ERBT and to report the current evidence for each technique.

\section{Methods}

Following prospective study registration (PROSPERO: CRD42020223162) a systematic review of MEDLINE/EMBASE/Scopus databases was performed by two reviewers, using free-text and MESH term combinations ("en bloc"/“ERBT"/“bladder"/“urinary bladder neoplasm”). English language, full-text papers published pre-July 2021 were eligible. Case reports, animal studies and non-transurethral studies were excluded. Data was extracted by a template and narrative synthesis performed. Variables recorded included study design, technique, feasibility of ERBT, size of bladder tumours resected, tumour location, obturator kick reflex for lateral wall tumours, complication data, specimen quality and presence of detrusor muscle, $\mathrm{T}$ stage and recurrence data where available. Risk of bias was assessed using the RoB 2 tool $^{10}$ for randomised studies (outcome options: low/some concerns/high) and the ROBINS- 1 tool ${ }^{11}$ (outcome options: risk low/moderate/ serious /critical/no information) for non-randomised comparative studies.

\section{Results}

\section{Literature review}

Search strategy produced a total of 2,067 results, yielding 1,109 unique abstracts or articles following removal of duplicates. After screening, 48 full-text papers were included for narrative synthesis (21 (19 unique cohorts) relating to electrocautery ERBT, 20 to laser ERBT, 3 to hydrodissection/electrocautery ERBT, 3 to polypectomy snare ERBT and 3 to mixed cohorts). Findings are discussed below and presented in Tables 1-3.

\section{Principles and general techniques}


En bloc resection of a bladder tumour (EBRT) is generally described with the use of a continuous flow resectoscope, with sheath size $22-27 \mathrm{Fr}^{12-14}$ A laser guide probe may be used with laser. ${ }^{14}$ The choice of irrigation fluid relates to the energy source in use - glycine or mannitol is used in monopolar electrocautery (including monopolar HybridKnife $\mathbb{R})^{15-18}$ and $0.9 \% \mathrm{NaCl}$ is widely used for bipolar electrocautery ${ }^{19-21}$ and laser. ${ }^{22-25}$ Distilled water has also been used with laser. ${ }^{14}$ Authors describe demarcation of the tumour edge with the energy source in use, generally with a $2-10 \mathrm{~mm}$ margin of macroscopically normal bladder mucosa, ${ }^{13-15,19-21,25-31}$ margins of up to $2 \mathrm{~cm}$ have been described. The optimal margin has not been determined. The clinical significance of positive horizontal margins remains uncertain, whilst positive vertical margins appear associated with residual tumour on reresection of T1 disease. ${ }^{21}$ Where electrocautery or combined electrocautery/waterjet is the energy source in use, the coagulation current is sometimes advocated for this step. ${ }^{15,20,28,32,33}$ With the use of laser technology, some authors alter the energy settings to provide a coagulation effect for the

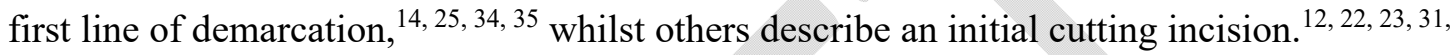
${ }^{36}$ The line of demarcation in the bladder mucosa is deepened to the level of detrusor muscle using the energy source of choice, vertically ${ }^{25}$ or in a 'fan' shape. ${ }^{30}$ The deepening technique may involve, for example, 'flash-firing' short and rapid cutting current of an electrocautery loop, ${ }^{28}$ or laser 'cutting' or vapourisation. ${ }^{25}$ Blunt dissection to the muscularis layer has also been described. ${ }^{21}$ Dissection within the muscularis layer, using retrograde or combined retrograde-antegrade approaches, with energy and/or blunt dissection is performed, until the tumour is lifted free of the base en bloc. ${ }^{13,15,20,21,26-29,32}$ Blunt dissection is performed with the electrode in electrocautery series, and has been described in laser series with the tip of the laser fibre ${ }^{36}$ retracting peaks of a laser guide probe, ${ }^{14}$ or the tip of the resectoscope sheath. ${ }^{23}$, 25, 37, 38 The base and edges may be coagulated/fulgurated in the usual fashion where electrocautery is used, ${ }^{13,15,19}$ or 'coagulated' with laser. ${ }^{22-24,34,35,37,38}$ The tumour may then be extracted, using the resectoscope sheath and siphon effect, an Ellik evacuator, a tissue forceps, a laparoscopic grasping forceps or a specimen retrieval bag (Tables 1-3). Larger tumours, for example those $>3 \mathrm{~cm}$, may be divided within the bladder before extraction in a controlled fashion (Tables 1-3). Images 1-4 illustrate en bloc resection of a bladder tumour using an electrocautery loop.

\section{Electrocautery ERBT}

Use of electrocautery enables most surgeons to perform en bloc resection of bladder tumours (ERBT) with equipment already established in the unit for cTURBT. The findings of 19 papers evaluating electrocautery ERBT are presented in Table 1. Both monopolar and bipolar electrocautery have been used with success. The electrode of choice is most commonly a standard loop, 5, 13, 19, 26, 28, 32, 39, 40 which may be bent to 45 degrees to create an angled intersection with the bladder mucosa. ${ }^{5,13,26,32}$ Some authors have found a flat loop to be useful in ERBT, ${ }^{15,41}$ whilst others describe the use of a plasma button, ${ }^{19,}{ }^{20}$ Collin's knife, ${ }^{27,29}$ or needle electrode ${ }^{21}$ either alone or in conjunction with a loop electrode. A novel approach of primarily cold excision with Zedd excision scissors and minimal electrocautery has recently been described. ${ }^{18}$ The upper limit of tumour size for electrocautery ERBT has been set at $2 \mathrm{~cm}-6 \mathrm{~cm}, 5,13,18,40$ however 'larger' tumours (for example those $>3 \mathrm{~cm}$ ) may require 
division within the bladder prior to extraction. ${ }^{5,42}$ Analysis of ERBT feasibility confirms a decline with increasing tumour size with current technology, particularly above a threshold of $3 \mathrm{~cm} .{ }^{40}$ Whether controlled intravesical tumour division negates any of the hypothesized benefits of ERBT regarding tumour scatter is unknown. The majority of electrocautery ERBT papers include tumours of diverse locations within the bladder. Some authors, however, avoid ERBT of tumours in particular locations, such as the anterior wall or dome, ${ }^{15,27}$ or overlying the ureteric orifices. ${ }^{18,19}$ Conversely, one paper proposes that use of ERBT may in fact be superior to cTURBT around the ureteric orifices due to purported greater control of coagulation, having confirmed post-ERBT ureteric patency with indigo carmine. ${ }^{41}$

Occurrence of the obturator nerve reflex is reported in $0-23 \%$ of electrocautery ERBT studies, where discussed. ${ }^{16,18,19,21,27,28,42}$ It is difficult to draw precise conclusions on this figure in the absence of detailed, comparable data surrounding lateral wall tumour location and anaesthesia. A bladder perforation rate of $0-5 \% 15,16,18,21,26-29$ and a bleeding rate of $0-7.3 \%, 5,15,18-21,26-29,40,42$ allowing for heterogeneity in definition of significant bleeding, are associated with electrocautery ERBT. Bladder perforation rates show no statistically significant difference to cTURBT controls in 3 non-randomised comparative studies. ${ }^{26,28,41}$ Detrusor muscle sampling rates of $>80 \%$ are associated with electrocautery ERBT in all studies where this is reported; rates of $\geq 90 \%$ are reported in 13 of 16 studies (on propensity score matching in one). ${ }^{8,13,15,18-21,26-29,41,43}$ In comparative studies, 4 of 5 papers found electrocautery ERBT to result in higher rates of muscularis identification compared to cTURBT controls $(p<0.01) .{ }^{26,28,29,43}$ One study reported equal detrusor sampling rates between ERBT and cTURBT, however 100\% sampling rates were achieved in each arm. ${ }^{19}$ Decreased cautery artefact in ERBT compared to controls was observed in some studies, ${ }^{19,28}$ and improved T1 substaging with ERBT has been reported also. ${ }^{44-46}$ Duration of irrigation and catheter time vary between studies and are likely influenced by local practice; no clear difference is apparent between ERBT and cTURBT. ${ }^{28,29,43}$ Where risk stratified, recurrence rates in the range of $0-11.5 \%$ for low risk and $25.5-29.86 \%$ for high risk bladder cancer at $12-18$ months were reported. ${ }^{20,42}$ Three relatively small studies reported decreased recurrence rates with ERBT compared to cTURBT at 3-39 month follow-up; ${ }^{19,32,43}$ whilst three other comparative studies identified no difference in recurrence rates at $3-18$ month follow up..$^{28,29,41}$ Evaluation of recurrence is limited by heterogenous risk stratification, reporting, intravesical treatment regimens and follow-up protocols.

\section{Laser ERBT}

The principles of laser ERBT involve the use of laser beams, of which a variety of wavelengths and penetration depths may be obtained, to separate, incise or vaporise tissue layers to dissect a bladder lesion free from its base and surrounding tissues. ${ }^{47}$ Multiple laser subtypes have been used to perform ERBT, and none has proven clear superiority. Endoscopic laser resection is often considered a safe technique without cessation of antiplatelet or anti-coagulant drugs, potentially a great advantage to its use. ${ }^{47}$ The numbers of patients taking such medications is, however, poorly reported in laser ERBT series throughout the literature. Twenty papers presenting findings of ERBT are outlined in Table 2. Laser ERBT of tumours up to $4.5-5.5 \mathrm{~cm}$ in diameter is reported. ${ }^{12,14,23,48}$ Whilst some series 
do not include tumours located at the dome or anterior wall of the bladder, ${ }^{14,35,38}$ others have

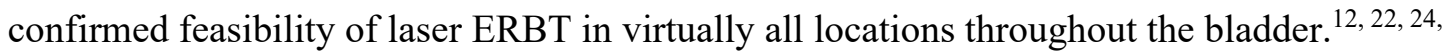
$30,34,37,48,49$ Some authors describe a specific technique ${ }^{22}$ or use a flexible cystoscope ${ }^{24}$ to approach lesions located at the dome. No occurrences of an obturator nerve reflex (ONR) were identified from the literature, and a statistically significant reduction in ONR with laser versus cTURBT has been described in several comparative studies. ${ }^{14,30,31,34,36,37,49,50}$ Rates of bladder perforation are described at $0-1.4 \%,{ }^{12,14,22-25,30,34,35,37,38,42,48,49,51}$ although this was not specifically reported in five studies. It is noteworthy that the majority of published studies evaluate outcomes of single or limited-number experienced operators. Bladder perforation rates were lower with laser ERBT than cTURBT in two studies, ${ }^{14,31}$ but did not appear to differ in other comparative studies.

A bleeding rate of $0-5.97 \%$ is reported, ${ }^{12,14,22-24,31,34,35,37,38,42,48,49}$ although complicated by non-uniform definitions and unclear use of anti-platelets/coagulants. Histological identification of muscularis propria fibres was confirmed in $80-100 \%$ of laser ERBT specimens in 14 studies, ${ }^{12,14,22,23,25,30,31,35-38,42,48,52}$ although in only $30.7 \%$ of specimen in one study. ${ }^{52}$ Detrusor sampling rate demonstrate statistically significant superiority to cTURBT controls. ${ }^{12,14,31,36,37,52}$ Cautery artefact appears reduced with laser ERBT, ${ }^{14}$ and improved identification of muscularis mucosa layer ${ }^{30}$ and $\mathrm{T} 1$ substaging $^{14}$ with laser ERBT versus cTURBT has also been described, although remaining limited. Variable durations of bladder irrigation and catheter time post laser ERBT are reported, likely reflecting surgeon practice. Some authors report irrigation to rarely be necessary following ERBT, ${ }^{23,25,35}$ or advocate use for a short period of several hours only. ${ }^{31,37}$ Urethral catheter time varies from mean 1.76 - 5 days. ${ }^{12,14,22,31,42}$ Several comparative studies have found a

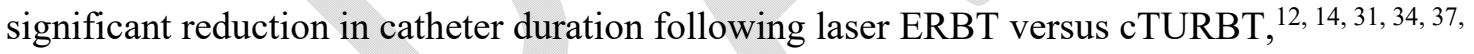
49 and one blinded comparative study found catheter duration to be similar. ${ }^{30}$ Whilst one study $(\mathrm{n}=64)$ reports lower recurrence and progression rates with laser ERBT as compared to cTURBT at 12 month follow-up, these results are not reiterated in other literature. Laser ERBT does not appear to alter the recurrence rate of non-muscle invasive bladder cancer compared to cTURBT controls at mean 12 - 41 month follow-up based on findings of nine studies, three of which risk stratified the patients in each group according to EAU guidelines. ${ }^{12,14,30,31,34,37,42,48,49}$ The authors of one such study reported that it was underpowered to the question of recurrence however, and identified a reduced rate of residual disease at routine 4 week re-resection following ERBT versus cTURBT $(p=0.01) .{ }^{14}$ Risk reduction in recurrence of high-risk bladder cancer with maintenance Pirarubicin following laser ERBT was reported in one series, ${ }^{38}$ however this was the drug of choice due to unavailability of BCG in the region in question. No additional oncological benefit was demonstrated with use of overnight saline irrigation following Thulium ERBT and intravesical Pirarubicin in one study. ${ }^{25}$ Further studies of intravesical regimens post ERBT are awaited. 


\section{Waterjet hydrodissection}

Waterjet technology employs a high pressure jet of fluid to divide tissues with hydroabrasive energy, with a unique level of tissue selectivity reported. ${ }^{53,54}$ Four studies identified described the use of hydrodissection to perform ERBT (Table 3). ${ }^{17,33,55,56}$ Hydrodissection was combined with electrosurgery via a HybridKnife ${ }^{\circledR}$ (ERBE, Tübingen, Germany) in all of these studies. HybridKnife ${ }^{\circledR}$ technique may begin with demarcation of the perimeter of the lesion to be resected with the electrocautery function, ${ }^{33}$ followed by waterjet function used to elevate the mucosa to be excised, creating a 'cushion' underneath it. Indigo-carmine colouration of the saline fluid can be used to assist visualisation. ${ }^{56}$ The electrocautery function is used to incise the tissues allowing en bloc resection, and to coagulate the base. ${ }^{33}$ HybridKnife ${ }^{\circledR}$ en bloc resection appears feasible for papillary bladder lesions $\leq 4 \mathrm{~cm}$, with a low complication rate. Compared to cTURBT controls, Cheng et al found the occurrence of ONR and pooled complications to be lower in the HybridKnife ${ }^{\circledR}$ en bloc group, $p=0.034 .{ }^{17}$ Gakis et al., in the only randomised study, did not observe a difference in complications

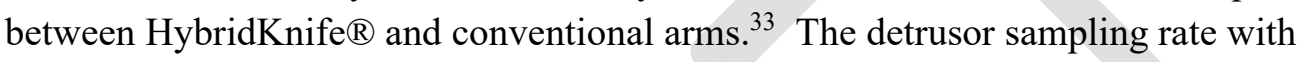
HybridKnife ${ }^{\circledR}$ EBRT is inconsistently reported and confounded by differing techniques, with some authors performing separate cold cup muscle biopsies. ${ }^{17,55}$ High rates of muscularis sampling appear achievable based on the $77 \%$ reported by Gakis et al, although statistical superiority to cTURBT in muscle sampling is unproven. ${ }^{33}$ Mean postoperative catheter time varied $1.6-2.5$ days in all studies, with Cheng et al. observing mean 9 hours less irrigation time and 1 day less catheter time than controls. ${ }^{17}$

\section{Polypectomy snare}

A limited amount of literature pertains to the use of electrosurgical polypectomy snares, such as those used in gastrointestinal endomucosal resection, for ERBT (Table 4). All identified papers used this technique in combination with another, for example cold cup biopsy of the tumour base,${ }^{57}$ conventional TURBT of the tumour base, ${ }^{58}$ or en bloc resection of the tumour base. ${ }^{59}$ Muscularis sampling rates of up to $75 \%$ are reported from the very small case series $;{ }^{58}$ however authors advocate the technique as a debulking strategy prior to formal sampling of the tumour bed. Polypectomy snare TURBT has been proposed to allow relatively removal of tumours that may be too large for conventional ERBT, with lesions $>5 \mathrm{~cm}$ excised, ${ }^{57,59}$ and to potentially pose a more time efficient strategy to removal of large bladder tumours, although the latter is unproven in the literature. ${ }^{59}$

\section{ERBT techniques compared}

A small number of studies compare different modalities of ERBT. In comparison of electrocautery (monopolar or bipolar) and laser (holmium or thulium) ERBT, Kramer et al. found no difference in clinically relevant complications, detrusor muscle sampling, irrigation or catheter time. ${ }^{42}$ The electrocautery ERBT group was associated with a higher conversion rate to conventional TURBT and with a greater decrease in haemoglobin compared to laser ERBT; however the absolute change in haemoglobin was low $(<0.5 \mathrm{~g} / \mathrm{dL})$. Similarly, Yang et al $(n=162)$ found no difference in complication rates between bipolar and holmium laser ERBT groups, although noted increased ONR with bipolar ERBT versus laser ERBT. ${ }^{60}$ 
Kramer et al. ( $\mathrm{n}=221$, prospective multicentre trial) found no difference in recurrence rates at 12 month follow-up with electrocautery versus laser ERBT. ${ }^{42}$ Conversely, Li et al. in a retrospective study $(n=115)$ reported a lower recurrence rate at 24 months with the use of electrocautery ERBT via a pin shaped electrode as compared to holmium laser ERBT and to conventional TURBT, preserved at multivariate analysis $(p=0.023) ;{ }^{61}$ complication rates were not discussed. A histopathological study of ERBT specimen found no statistically significant difference in rates of muscularis muscle sampling or in confirmation of tumour architecture to be associated with the energy source used during resection (electrocautery, thulium laser or HybridKnife $\left({ }^{\circledR}\right)$, although sample size was small $(\mathrm{n}=34) .{ }^{62}$

\section{Maximum tumor size}

The upper limit of tumour size is set at $3 \mathrm{~cm}$ or $4 \mathrm{~cm}$ in many series, as outlined in the data tables. This historically appears to have been an arbitrary measurement, however a marked decline in technical success rates $(29.6 \%$ vs $84.3 \%$ for tumours $>3 \mathrm{~cm}$ vs those $\leq 3 \mathrm{~cm})$ has recently been confirmed. ${ }^{40}$ Nonetheless, ERBT of tumours up to $6 \mathrm{~cm}$ in size is reported, with factors such as tumour location and morphology perhaps exerting an influence. ${ }^{40}$ Pertinently, larger tumours may require modified extraction techniques, or intra-vesical division prior to extraction. ${ }^{5,42}$ The oncological impact of this is uncertain. There is currently inadequate stratification of outcome data according to tumour size in the literature to assess any influence that tumour size may bear on surgical complications.

\section{En bloc techniques for re-resection}

One paper $(\mathrm{n}=78)$ evaluated the use of ERBT in re-resection of high risk bladder cancer within 40 days of initial diagnostic ERBT. ${ }^{63}$ Re-resection of the visualised scar with a J electrode (Collins loop) was feasible in all cases and safe, with no instances of bladder perforation or uncontrollable bleeding. Tumours of the anterior or posterior wall and those covering ureteric orifices were excluded. Detrusor muscle was obtained in all samples. A low rate of residual disease (pTa high grade in 1/78, carcinoma in situ in 4/78) and no cases of muscle invasive disease, were identified at re-resection. These figures are lower than previous literature assessing re-resection of high-risk disease would estimate, ${ }^{64}$ perhaps suggesting a superior initial resection with ERBT, but further analysis of such a hypothesis would be required.

\section{Enhanced visualisation techniques for ERBT}

The utility of enhanced visualisation techniques during ERBT has been poorly explored. Photodynamic diagnosis, ${ }^{33,41,56,65}$ narrowband imaging ${ }^{17,21}$ and near-infrared molecular imaging ${ }^{16}$ techniques have been described in a small number of studies using electrocautery and hydrodissection. Presumably enhanced visualisation techniques would offer similar advantage for ERBT as for cTURBT, however further ERBT-specific exploration is required.

\section{Risk of bias}

Estimated risk of bias $(\mathrm{RoB})$ for randomised or other comparative studies is presented within the data tables. RoB was assessed 'in general' (including feasibility/safety/pathological results/other non-recurrence related primary endpoint) and 'regarding recurrence.' The 
majority of studies were deemed to contain moderate RoB 'in general' due to selection and/or operator bias (non-randomised studies) and due to the subjectivity of clinical outcomes such as bleeding, irrigation time and catheter duration, which were generally not assessed/reported as assessed by a blinded researcher. Many studies were deemed at 'serious' RoB regarding recurrence, predominantly due to lack of clarity regarding risk stratification, intravesical treatment regimens or other potential confounders.

\section{Conclusions}

En bloc resection of bladder tumours is feasible using a variety of techniques and energy sources, which are synthesised in this review. ERBT is safe, with a consistently low complication rate, and a rate of detrusor muscle sampling that appears to exceed that of cTURBT. Comparative evidence is limited by a lack of large prospective, randomised studies, although these may be anticipated. ${ }^{66}$ The use of laser energy sources may eliminate obturator nerve reflex activation, potentially providing a safer approach to resections of lesions on the lateral wall. Otherwise, no definitive superiority of any energy source has been confirmed in ERBT. Doubtlessly, surgeon experience with a particular technology is of relevance. Current evidence suggests that recurrence rates of non-muscle invasive bladder cancer at short to medium term follow-up are similar between risk-stratified ERBT and cTURBT groups, but further research into the potential impact of ERBT on residual disease, recurrence and progression is merited.

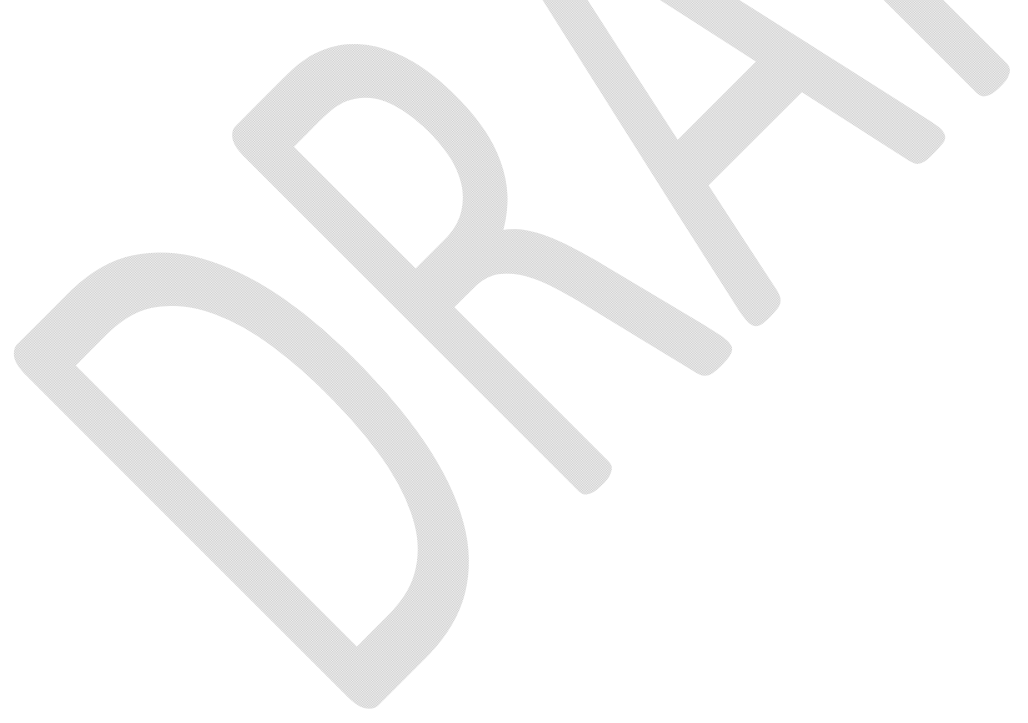




\section{References}

1. Mohammadian M, Safari A, Allah Bakeshei K, et al. Recent Patterns of Bladder Cancer Incidence and Mortality: A Global Overview. World Cancer Research Journal 2020; 7: e1464.

2. Christie A. Transurethral Resection of Bladder Tumors. Philadelphia, PA: ELSEVIER, 2019.

3. Albarran J and Imbert L. Les Tumeurs du Rein. Paris: Masson, 1903, p. 452-59.

4. Kitamura K, Kataoka K, Fujioka H, et al. Transurethral resection of a bladder tumor by the use of a polypectomy snare. J Urol 1980; 124: 808-9. 1980/12/01.

5. Ukai R, Kawashita $\mathrm{E}$ and Ikeda H. A new technique for transurethral resection of superficial bladder tumor in 1 piece. J Urol 2000; 163: 878-9. 2000/02/25.

6. Lundy J. Principles and Practice of Surgical Oncology: The Influence of Present Day Concepts of Tumor Biology. In: A.L. G (ed) Cancer Management in Man Cancer Growth and Progression. Dordrecht: Springer,, 1989, pp.145-48.

7. Mostafid H, Kamat AM, Daneshmand S, et al. Best Practices to Optimise Quality and Outcomes of Transurethral Resection of Bladder Tumours. Eur Urol Oncol 2020 2020/07/21. DOI: 10.1016/j.euo.2020.06.010.

8. Kramer MW, Altieri V, Hurle R, et al. Current Evidence of Transurethral En-bloc Resection of Nonmuscle Invasive Bladder Cancer. Eur Urol Focus 2017; 3: 567-76. 2017/07/30. DOI: 10.1016/j.euf.2016.12.004.

9. Yanagisawa T, Yorozu T, Miki J, et al. Feasibility and accuracy of pathological diagnosis in en bloc resection versus conventional transurethral resection of bladder tumor: Evaluation with pT1 sub-staging by 10 pathologists. Histopathology 2020 2020/11/28. DOI: 10.1111/his.14307.

10. Sterne JAC, Savovic J, Page MJ, et al. RoB 2: a revised tool for assessing risk of bias in randomised trials. BMJ 2019; 366: 14898. 2019/08/30. DOI: 10.1136/bmj.14898.

11. Sterne JA, Hernan MA, Reeves BC, et al. ROBINS-I: a tool for assessing risk of bias in non-randomised studies of interventions. BMJ 2016; 355: i4919. 2016/10/14. DOI: 10.1136/bmj.i4919.

12. $\mathrm{Xu} \mathrm{H}, \mathrm{Ma}$ J, Chen Z, et al. Safety and Efficacy of En Bloc Transurethral Resection With 1.9 microm Vela Laser for Treatment of Non-Muscle-invasive Bladder Cancer. Urology 2018; 113: 246-50. 2017/12/05. DOI: 10.1016/j.urology.2017.11.030.

13. Eissa A, Zoeir A, Ciarlariello S, et al. En-bloc resection of bladder tumors for pathological staging: the value of lateral margins analysis. Minerva Urol Nefrol 2020; 72: 763-69. 2020/02/01. DOI: 10.23736/S0393-2249.20.03551-1.

14. Hashem A, Mosbah A, El-Tabey NA, et al. Holmium Laser En-bloc Resection Versus Conventional Transurethral Resection of Bladder Tumors for Treatment of Nonmuscle-invasive Bladder Cancer: A Randomized Clinical Trial. Eur Urol Focus 2020 2021/01/03. DOI: 10.1016/j.euf.2020.12.003.

15. Lodde M, Lusuardi L, Palermo S, et al. En bloc transurethral resection of bladder tumors: use and limits. Urology 2003; 62: 1089-91. 2003/12/11. DOI: 10.1016/s00904295(03)00761-1.

16. Yang Y, Yang X, Liu C, et al. Preliminary study on the application of en bloc resection combined with near-infrared molecular imaging technique in the diagnosis and treatment of bladder cancer. World J Urol 2020; 38: 3169-76. 2020/03/05. DOI: 10.1007/s00345-020-03143-w.

17. Cheng YY, Sun Y, Li J, et al. Transurethral endoscopic submucosal en bloc dissection for nonmuscle invasive bladder cancer: A comparison study of HybridKnife-assisted 
versus conventional dissection technique. J Cancer Res Ther 2018; 14: 1606-12. 2018/12/28. DOI: $10.4103 /$ jcrt.JCRT 786 17.

18. Bmz H, Hegde P, Shah M, et al. Cold en bloc excision (CEBE) of bladder tumours using Zedd excision scissors: a prospective, pilot, safety and feasibility study. Ther Adv Urol 2020; 12: 1756287220972230. 2020/12/10. DOI: 10.1177/1756287220972230.

19. Balan GX, Geavlete PA, Georgescu DA, et al. Bipolar en bloc tumor resection versus standard monopolar TURBT - which is the best way to go in non-invasive bladder cancer? Rom J Morphol Embryol 2018; 59: 773-80. 2018/12/12.

20. Zhang J, Wang L, Mao S, et al. Transurethral en bloc resection with bipolar button electrode for non-muscle invasive bladder cancer. Int Urol Nephrol 2018; 50: 619-23. 2018/02/27. DOI: 10.1007/s11255-018-1830-0.

21. Yanagisawa T, Miki J, Sakanaka K, et al. Clinical Significance of Horizontal and Vertical Margin of En Bloc Resection for Nonmuscle Invasive Bladder Cancer. J Urol 2021; 206: 252-59. 2021/03/30. DOI: 10.1097/JU.0000000000001735.

22. Maheshwari PN, Arora AM, Sane MS, et al. Safety, feasibility, and quality of holmium laser en-bloc resection of nonmuscle invasive bladder tumors - A single-center experience. Indian J Urol 2020; 36: 106-11. 2020/06/19. DOI: 10.4103/iju.IJU_348_19.

23. Muto G, Collura D, Giacobbe A, et al. Thulium:yttrium-aluminum-garnet laser for en bloc resection of bladder cancer: clinical and histopathologic advantages. Urology 2014; 83: 851-5. 2014/02/20. DOI: 10.1016/j.urology.2013.12.022.

24. Zhang Z, Zeng S, Zhao J, et al. A Pilot Study of Vela Laser for En Bloc Resection of Papillary Bladder Cancer. Clin Genitourin Cancer 2017; 15: e311-e14. 2017/01/24. DOI: $10.1016 / j . c l g c .2016 .06 .004$.

25. Yang Y, Liu C, Yan X, et al. Overnight Continuous Saline Bladder Irrigation After En Bloc Resection of Bladder Tumor Does Not Improve Oncological Outcomes in Patients Who Have Received Intravesical Chemotherapy. Front Oncol 2021; 11: 638065. 2021/03/30. DOI: 10.3389/fonc.2021.638065.

26. Upadhyay R, Kapoor R, Srivastava A, et al. Does En-bloc transurethral resection of bladder tumor give a better yield in terms of presence of detrusor muscle in the biopsy specimen? Indian J Urol 2012; 28: 275-9. 2012/12/04. DOI: 10.4103/09701591.102700 .

27. Hurle R, Lazzeri M, Colombo P, et al. "En Bloc" Resection of Nonmuscle Invasive Bladder Cancer: A Prospective Single-center Study. Urology 2016; 90: 126-30. 2016/01/19. DOI: 10.1016/j.urology.2016.01.004.

28. Zhang KY, Xing JC, Li W, et al. A novel transurethral resection technique for superficial bladder tumor: retrograde en bloc resection. World J Surg Oncol 2017; 15: 125. 2017/07/08. DOI: 10.1186/s12957-017-1192-6.

29. Bangash M, Ather MH, Khan N, et al. Comparison Of Recurrence Rate Between "EN BLOC" Resection Of Bladder Tumour And Conventional Technique For Non-Muscle Invasive Bladder Cancer. J Ayub Med Coll Abbottabad 2020; 32: 435-40. 2020/11/24.

30. Fan J, Wu K, Zhang N, et al. Green-light laser en bloc resection versus conventional transurethral resection for initial non-muscle-invasive bladder cancer: A randomized controlled trial. Int J Urol 2021 2021/05/21. DOI: 10.1111/iju.14592.

31. Liu Z, Zhang Y, Sun G, et al. Comparison of Thulium Laser Resection of Bladder Tumors and Conventional Transurethral Resection of Bladder Tumors for Non-MuscleInvasive Bladder Cancer. Urol Int 2021: 1-6. 2021/03/31. DOI: 10.1159/000514042.

32. Sureka SK, Agarwal V, Agnihotri S, et al. Is en-bloc transurethral resection of bladder tumor for non-muscle invasive bladder carcinoma better than conventional technique in 
terms of recurrence and progression?: A prospective study. Indian J Urol 2014; 30: 144-9. 2014/04/20. DOI: 10.4103/0970-1591.126887.

33. Gakis G, Karl A, Bertz S, et al. Transurethral en bloc submucosal hydrodissection vs conventional resection for resection of non-muscle-invasive bladder cancer (HYBRIDBLUE): a randomised, multicentre trial. BJU Int 2020; 126: 509-19. 2020/06/25. DOI: 10.1111/bju.15150.

34. Chen J, Zhao Y, Wang S, et al. Green-light laser en bloc resection for primary nonmuscle-invasive bladder tumor versus transurethral electroresection: A prospective, nonrandomized two-center trial with 36-month follow-up. Lasers Surg Med 2016; 48: 859-65. 2016/10/26. DOI: 10.1002/1sm.22565.

35. He D, Fan J, Wu K, et al. Novel green-light KTP laser en bloc enucleation for nonmuscle-invasive bladder cancer: technique and initial clinical experience. $J$ Endourol 2014; 28: 975-9. 2014/04/17. DOI: 10.1089/end.2013.0740.

36. Cheng B, Qiu X, Li H, et al. The safety and efficacy of front-firing green-light laser endoscopic en bloc photoselective vapo-enucleation of non-muscle-invasive bladder cancer. Ther Clin Risk Manag 2017; 13: 983-88. 2017/09/02. DOI: 10.2147/TCRM.S141900.

37. Li K, Xu Y, Tan M, et al. A retrospective comparison of thulium laser en bloc resection of bladder tumor and plasmakinetic transurethral resection of bladder tumor in primary non-muscle invasive bladder cancer. Lasers Med Sci 2019; 34: 85-92. 2018/09/02. DOI: $10.1007 / \mathrm{s} 10103-018-2604-8$.

38. $\mathrm{Xu} \mathrm{S}, \mathrm{Tan} \mathrm{S}, \mathrm{Wu} \mathrm{T}$, et al. The value of transurethral thulium laser en bloc resection combined with a single immediate postoperative intravesical instillation of pirarubicin in primary non-muscle-invasive bladder cancer. Lasers Med Sci 2020; 35: 1695-701. 2020/01/24. DOI: 10.1007/s10103-020-02960-0.

39. Huang H, Wang T, Ahmed MG, et al. Retrograde en bloc resection for non-muscle invasive bladder tumor can reduce the risk of seeding cancer cells into the peripheral circulation. World J Surg Oncol 2020; 18: 33. 2020/02/12. DOI: 10.1186/s12957-0201808-0.

40. Teoh JY, Mayor N, Li KM, et al. En-bloc resection of bladder tumour as primary treatment for patients with non-muscle-invasive bladder cancer: routine implementation in a multi-centre setting. World J Urol 2021 2021/03/29. DOI: 10.1007/s00345-02103675-9.

41. Miyake M, Nishimura N, Fujii T, et al. Photodynamic Diagnosis-Assisted En Bloc Transurethral Resection of Bladder Tumor for Nonmuscle Invasive Bladder Cancer: Short-Term Oncologic and Functional Outcomes. J Endourol 2020 2020/09/18. DOI: 10.1089/end.2020.0371.

42. Kramer MW, Rassweiler JJ, Klein J, et al. En bloc resection of urothelium carcinoma of the bladder (EBRUC): a European multicenter study to compare safety, efficacy, and outcome of laser and electrical en bloc transurethral resection of bladder tumor. World J Urol 2015; 33: 1937-43. 2015/04/26. DOI: 10.1007/s00345-015-1568-6.

43. Poletajew S, Krajewski W, Stelmach P, et al. En-bloc resection of urinary bladder tumour - a prospective controlled multicentre observational study. Wideochir Inne Tech Maloinwazyjne 2021; 16: 145-50. 2021/04/01. DOI: 10.5114/wiitm.2020.95399.

44. Yanagisawa T, Yorozu T, Miki J, et al. Feasibility and accuracy of pathological diagnosis in en-bloc transurethral resection specimens versus conventional transurethral resection specimens of bladder tumour: evaluation with pT1 substaging by 10 pathologists. Histopathology 2021; 78: 943-50. 2020/11/28. DOI: 10.1111/his.14307. 
45. Yanagisawa T, Miki J, Yorozu T, et al. Vertical Lamina Propria Invasion Diagnosed by En Bloc Transurethral Resection is a Significant Predictor of Progression for pT1 Bladder Cancer. J Urol 2021; 205: 1622-28. 2021/01/28. DOI: 10.1097/JU.0000000000001630.

46. Yasui M, Ohta JI, Aoki S, et al. Prognosis of patients with T1 bladder cancer after en bloc transurethral resection of bladder tumor stratified by invasion to the level of the muscularis mucosa. Int Urol Nephrol 2021; 53: 1105-09. 2021/01/03. DOI: 10.1007/s11255-020-02772-9.

47. Kramer MW, Bach T, Wolters M, et al. Current evidence for transurethral laser therapy of non-muscle invasive bladder cancer. World J Urol 2011; 29: 433-42. 2011/05/06. DOI: 10.1007/s00345-011-0680-5.

48. Migliari R, Buffardi A and Ghabin H. Thulium Laser Endoscopic En Bloc Enucleation of Nonmuscle-Invasive Bladder Cancer. J Endourol 2015; 29: 1258-62. 2015/06/24. DOI: 10.1089/end.2015.0336.

49. Chen X, Liao J, Chen L, et al. En bloc transurethral resection with 2-micron continuous-wave laser for primary non-muscle-invasive bladder cancer: a randomized controlled trial. World J Urol 2015; 33: 989-95. 2014/06/22. DOI: 10.1007/s00345014-1342-1.

50. Kristinsson S, Johnson $\mathrm{M}$ and Ralph D. Review of penile reconstructive techniques. Int J Impot Res 2020 2020/03/11. DOI: 10.1038/s41443-020-0246-4.

51. Tao W, Sun C, Yao Q, et al. The clinical study of en bloc transurethral resection with $980 \mathrm{~nm}$ laser for treatment of primary non-muscle invasive bladder cancer. J Xray Sci Technol 2020; 28: 563-71. 2020/04/01. DOI: 10.3233/XST-190616.

52. Liang H, Yang T, Wu K, et al. En bloc resection improves the identification of muscularis mucosae in non-muscle invasive bladder cancer. World J Urol 2019; 37: 2677-82. 2019/03/05. DOI: 10.1007/s00345-019-02672-3.

53. Papachristou DN and Barters R. Resection of the liver with a water jet. Br J Surg 1982; 69: 93-4. 1982/02/01. DOI: 10.1002/bjs.1800690212.

54. Hreha P, Hloch S and al. e. Water Jet Technology Used in Medicine. Technicki Vjesnik 2010; 17(2): 237-40.

55. Nagele U, Kugler M, Nicklas A, et al. Waterjet hydrodissection: first experiences and short-term outcomes of a novel approach to bladder tumor resection. World J Urol 2011; 29: 423-7. 2011/02/10. DOI: 10.1007/s00345-011-0653-8.

56. Fritsche HM, Otto W, Eder F, et al. Water-jet-aided transurethral dissection of urothelial carcinoma: a prospective clinical study. J Endourol 2011; 25: 1599-603. 2011/08/06. DOI: 10.1089/end.2011.0042.

57. Maurice MJ, Vricella GJ, MacLennan G, et al. Endoscopic snare resection of bladder tumors: evaluation of an alternative technique for bladder tumor resection. $J$ Endourol 2012; 26: 614-7. 2012/03/07. DOI: 10.1089/end.2011.0587.

58. Adam A, Sookram J, Bhattu AS, et al. Trans-Urethral Snare of Bladder Tumor (TUSnBT) with Stone Basket Retrieval: A Novel Time-Saving Technique in the Endoscopic Management of Papillary Bladder Lesions. Curr Urol 2018; 11: 189-95. 2018/07/13. DOI: 10.1159/000447217.

59. Hayashida Y, Miyata Y, Matsuo T, et al. A pilot study to assess the safety and usefulness of combined transurethral endoscopic mucosal resection and en-bloc resection for non-muscle invasive bladder cancer. BMC Urol 2019; 19: 56. 2019/06/27. DOI: $10.1186 / \mathrm{s} 12894-019-0486-0$. 
60. Yang D., Li H., Li X., et al. Retrospective complications assessment of en bloc resection of bladder tumors with the modified clavien classification system. Int J Clin Exp Med 2018; 11(8):8601-8607.

61. Li S, Jia Y, Yu C, et al. Influences of Different Operative Methods on the Recurrence Rate of Non-Muscle-Invasive Bladder Cancer. Urol J 2020: 5965. 2020/10/02. DOI: 10.22037/uj.v16i7.5965.

62. Struck JP, Kramer MW, Katzendorn O, et al. Bicentric Retrospective Analysis of en Bloc Resection and Muscularis Mucosae Detection Rate in Non-Muscle Invasive Bladder Tumors: A Real-World Scenario. Adv Ther 2020 2020/10/24. DOI: 10.1007/s12325-020-01529-1.

63. Hurle R, Casale P, Lazzeri M, et al. En bloc re-resection of high-risk NMIBC after en bloc resection: results of a multicenter observational study. World J Urol 2020; 38: 703-08. 2019/05/23. DOI: 10.1007/s00345-019-02805-8.

64. Cumberbatch MGK, Foerster B, Catto JWF, et al. Repeat Transurethral Resection in Non-muscle-invasive Bladder Cancer: A Systematic Review. Eur Urol 2018; 73: $925-$ 33. 2018/03/11. DOI: 10.1016/j.eururo.2018.02.014.

65. Miyake M, Nishimura N, Fujii T, et al. Photodynamic Diagnosis-Assisted En Bloc Transurethral Resection of Bladder Tumor for Nonmuscle Invasive Bladder Cancer: Short-Term Oncologic and Functional Outcomes. J Endourol 2021; 35: 319-27. 2020/09/18. DOI: 10.1089/end.2020.0371.

66. Miyake M, Nishimura N, Inoue T, et al. Fluorescent cystoscopy-assisted en bloc transurethral resection versus conventional transurethral resection in patients with nonmuscle invasive bladder cancer: study protocol of a prospective, open-label, randomized control trial (the FLEBER study). Trials 2021; 22: 136. 2021/02/14. DOI: 10.1186/s13063-021-05094-y.

67. Severgina L.O., Sorokin N.I. and A.M. D. Laser en-bloc resection of non-muscleinvasive bladder cancer: clinical and morphological specificities. Onkourologiya $=$ Cancer Urology 2018; 14(3): 78-84.

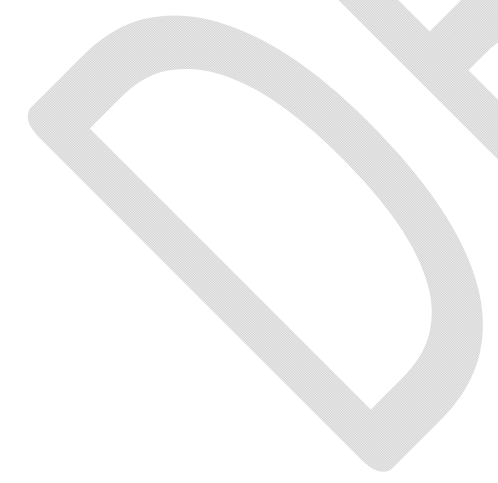




\section{Figures and Tables}

Fig. 1. Papillary bladder tumor is identified cystoscopically.
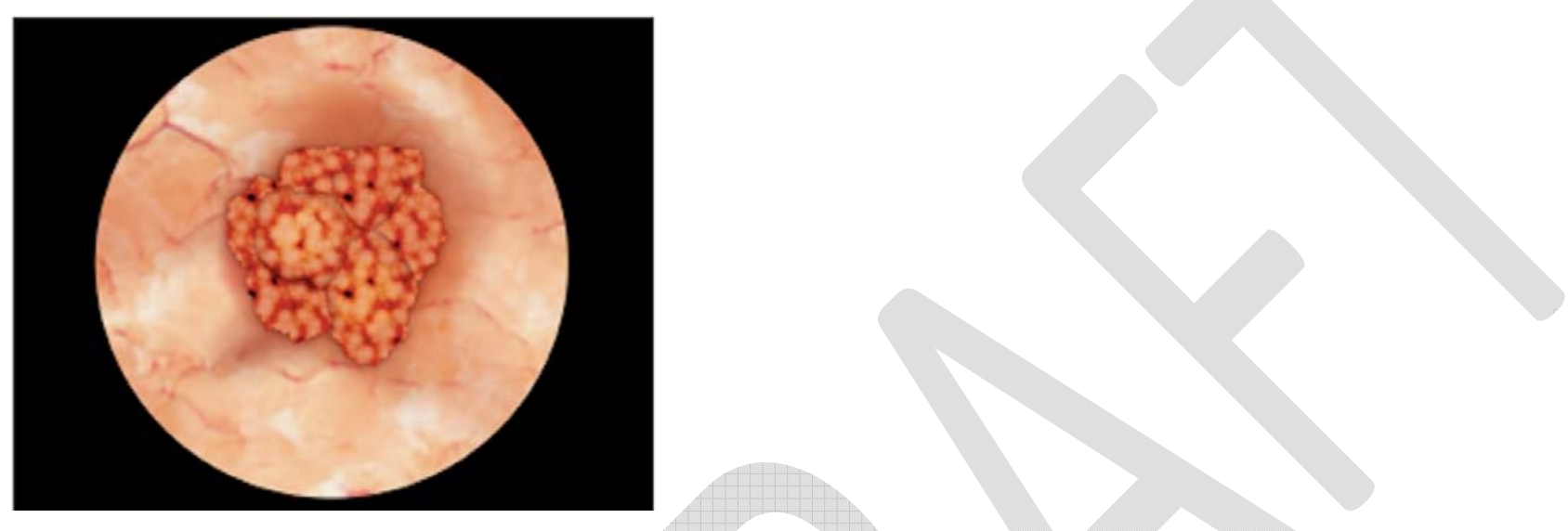

Fig. 2. The edges of the tumor are demarcated with a narrow margin of macroscopically normal mucosa.
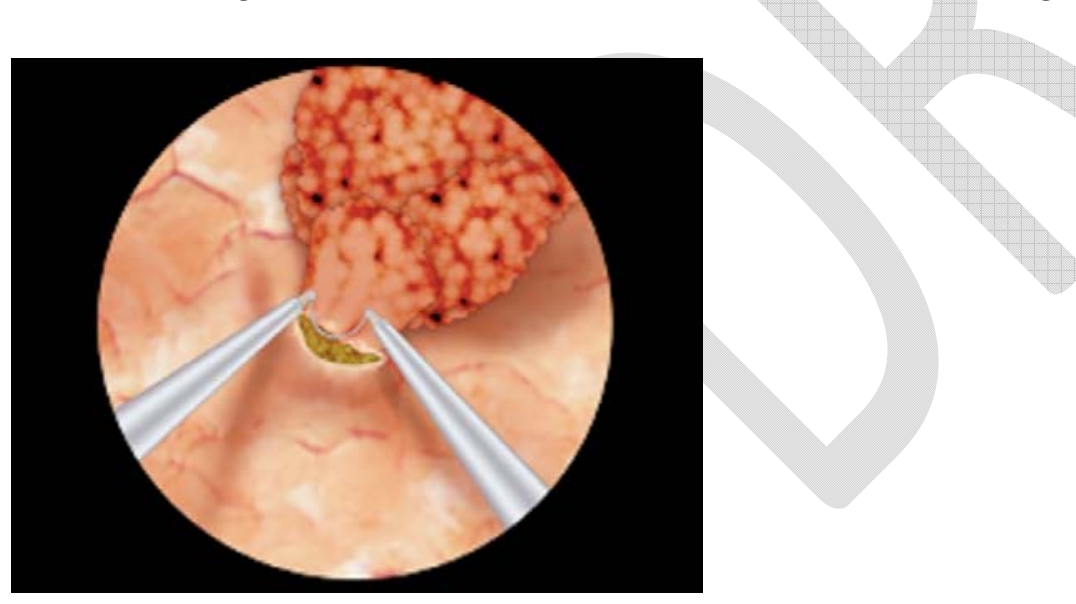
Fig. 3. The mucosa and lamina propria are incised until the muscularis propria is reached.

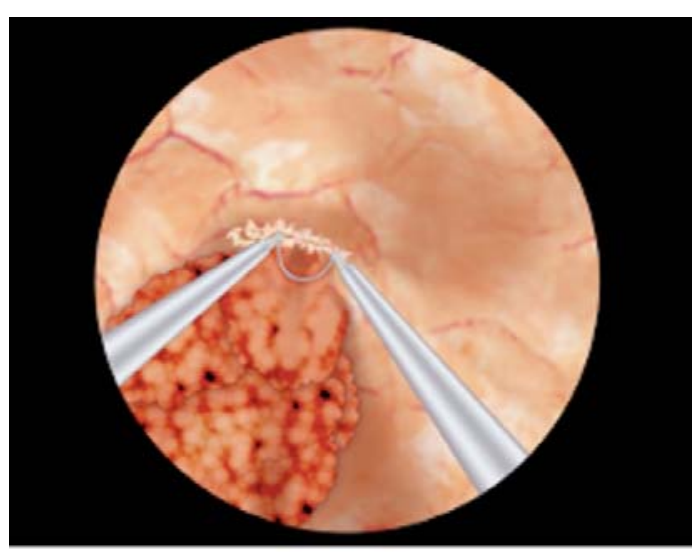

Fig. 4. Gradual tumor resection within the muscularis layer is continued until the tumor specimen is separated from its base 'en bloc.'

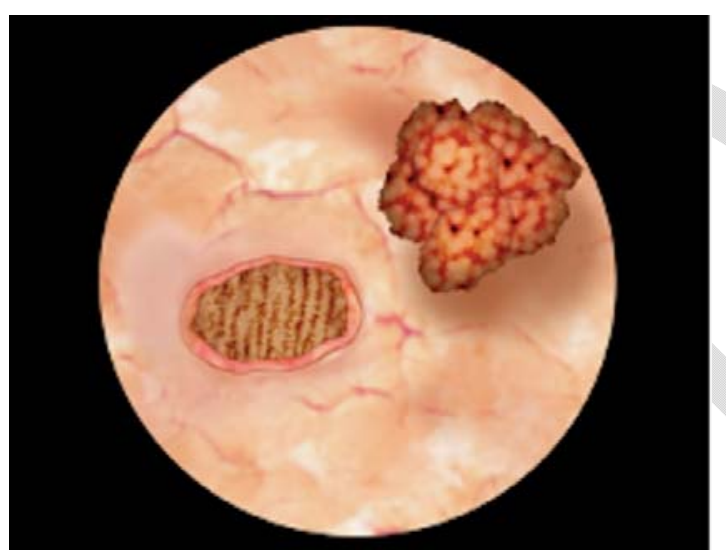




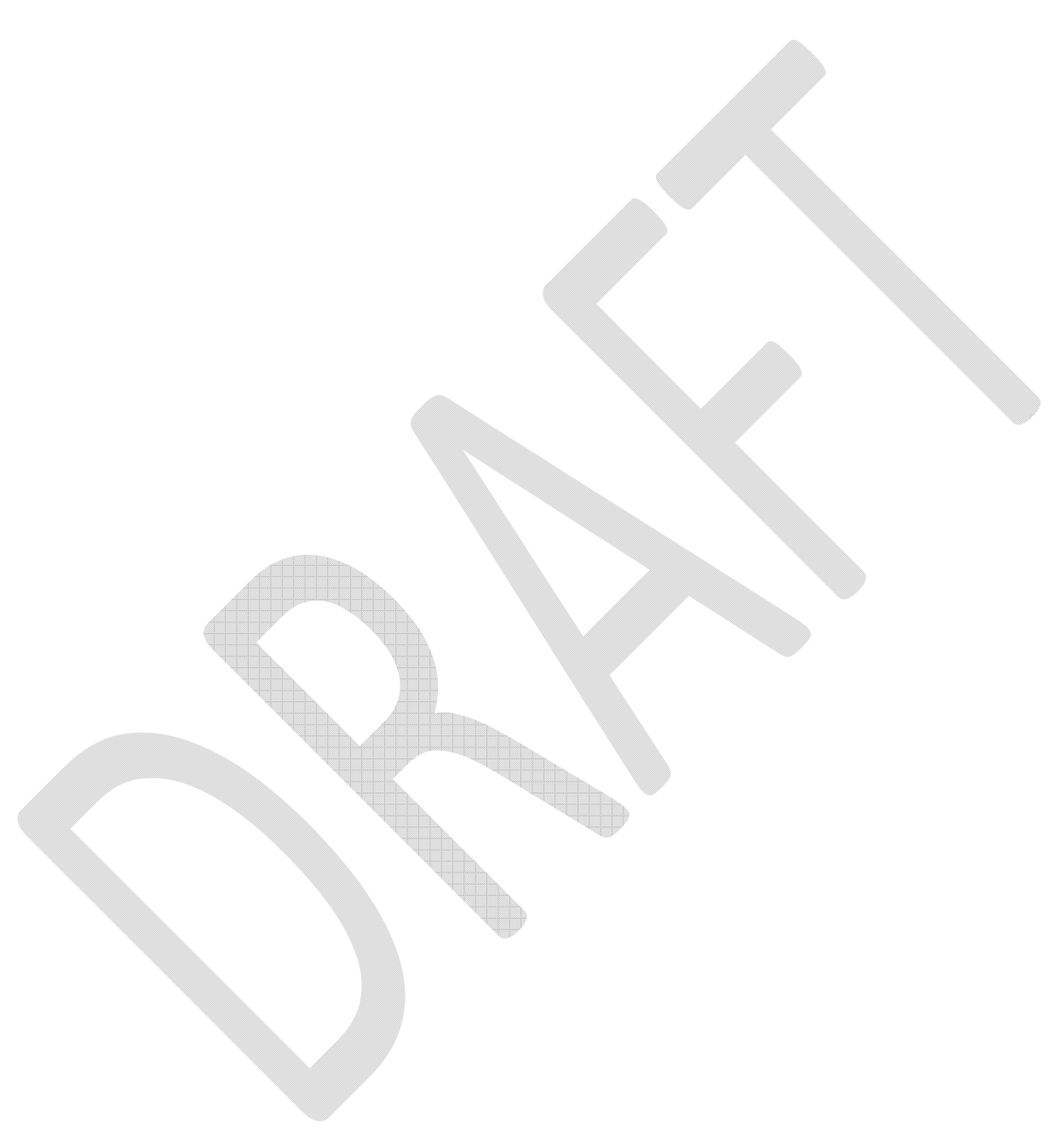


CUAJ - Review

Croghan et al

En bloc TURBT

\begin{tabular}{|c|c|c|c|c|c|c|c|c|c|c|c|c|c|c|c|c|c|c|}
\hline Author & $\mathbf{Y r}$ & $\begin{array}{l}\text { ERB } \\
T^{\wedge} \\
(\mathbf{n})\end{array}$ & $\begin{array}{l}\text { Mod- } \\
\text { ality }\end{array}$ & Design & $\begin{array}{l}\text { cTURBT } \\
\text { control } \\
\text { group? }\end{array}$ & $\begin{array}{l}\text { Age } \\
\text { (Avg) }\end{array}$ & $\begin{array}{l}\text { Male } \\
\%\end{array}$ & $\begin{array}{l}\text { Feas- } \\
\text { ibility }\end{array}$ & $\begin{array}{l}\text { Max. } \\
\text { tumor } \\
\text { size }\end{array}$ & Extraction & $\begin{array}{l}\text { Anes- } \\
\text { thesia }\end{array}$ & $\begin{array}{l}\text { Obtur- } \\
\text { ator } \\
\text { reflex }\end{array}$ & $\begin{array}{l}\text { Bladder } \\
\text { perforatio } \\
\text { n }\end{array}$ & $\begin{array}{l}\text { Signifi- } \\
\text { cant } \\
\text { bleeding } \\
* \\
\end{array}$ & $\begin{array}{l}\text { Muscularis } \\
\text { propria } \\
\text { identified in } \\
\text { specimen? }\end{array}$ & pTa & pT1 & $\geq \mathbf{p T 2}$ \\
\hline Lodde $^{15}$ & 2003 & 37 & \begin{tabular}{|l} 
Monop \\
olar \\
(flat \\
loop) \\
\end{tabular} & Prosp. & No & 64.7 & $\begin{array}{l}86.5 \% \\
(32 / 3 \\
7)\end{array}$ & All & $2.5 \mathrm{~cm}$ & Syr & Mixed & NR & $\begin{array}{l}2.7 \% \\
(1 / 37)\end{array}$ & None & $\begin{array}{l}100 \% \\
(37 / 37)\end{array}$ & $\begin{array}{l}82.25 \% \\
(51 / 62)^{*}\end{array}$ & $\begin{array}{l}17.8 \% \\
(11 / 6 \\
2)\end{array}$ & 0 \\
\hline $\mathrm{Ukai}^{5}$ & 2010 & 97 & $\begin{array}{l}\text { Energy } \\
\text { NR } \\
\text { (bent } \\
\text { loop) }\end{array}$ & Prosp. & No & 71.2 & $\begin{array}{l}85.5 \% \\
(83 / 9 \\
7)\end{array}$ & \begin{tabular}{|l|} 
Uncle \\
ar \\
(some \\
mixed \\
techni \\
que) \\
\end{tabular} & $5.5 \mathrm{~cm}^{\wedge}$ & $\mathrm{N}$ & Spinal & NR & $\begin{array}{l}\text { None } \\
(0 / 97)\end{array}$ & None & $\begin{array}{l}82.5 \% \\
(80 / 97)\end{array}$ & $\begin{array}{l}30.9 \% \\
(30 / 97)\end{array}$ & $\begin{array}{l}60.8 \% \\
(59 / 9 \\
7)\end{array}$ & $\begin{array}{l}7.21 \% \\
(7 / 97)\end{array}$ \\
\hline $\begin{array}{l}\text { Upadhya } \\
y^{26}\end{array}$ & 2012 & 21 & $\begin{array}{l}\text { Monop } \\
\text { olar } \\
\text { (bent } \\
\text { loop) }\end{array}$ & $\begin{array}{l}\text { Prosp. } \\
\text { Non- } \\
\text { Ran }\end{array}$ & Yes & NR & NR & All & $<3 \mathrm{~cm}$ & NR & $\begin{array}{l}\text { Gener } \\
\text { al for } \\
\text { lateral } \\
\text { wall; } \\
\text { other } \\
\text { wise } \\
\text { spinal }\end{array}$ & NR & $\begin{array}{l}\text { None } \\
(0 / 21)\end{array}$ & 0 & $\begin{array}{l}95.2 \% \\
(20 / 21)\end{array}$ & $\begin{array}{l}57.15 \% \\
(12 / 21)\end{array}$ & $\begin{array}{l}28.6 \% \\
(6 / 21)\end{array}$ & $\begin{array}{l}14.3 \% \\
(3 / 21)\end{array}$ \\
\hline \multicolumn{6}{|c|}{ Upadhyay control $n=25$} & & & & & & “" & - & $\begin{array}{l}4 \% \\
(1 / 25)\end{array}$ & 0 & $\begin{array}{l}60 \% \\
(15 / 25)\end{array}$ & $\begin{array}{l}48 \% \\
(12 / 25)\end{array}$ & $\begin{array}{l}32 \% \\
(8 / 25)\end{array}$ & $\begin{array}{l}20 \% \\
(5 / 25)\end{array}$ \\
\hline \multicolumn{6}{|c|}{ Statistical significance } & - & - & - & - & - & - & - & NS & - & $<0.001$ & NS & NS & NS \\
\hline Sureka $^{32}$ & 2014 & 21 & $\begin{array}{l}\text { Monop } \\
\text { olar } \\
\text { (bent } \\
\text { loop) } \\
\end{array}$ & $\begin{array}{l}\text { Prosp. } \\
\text { Non- } \\
\text { Ran }\end{array}$ & Yes & 52.6 & NR & All & $4 \mathrm{~cm}^{\wedge}$ & $\begin{array}{l}\text { Grasping } \\
\text { forceps via } \\
\text { nephroscop } \\
\text { e for large }\end{array}$ & NR & NR & NR & NR & $\begin{array}{l}\text { All, but } \\
\text { excluded if } \\
\text { muscle not } \\
\text { present }\end{array}$ & $\begin{array}{l}57.14 \% \\
(12 / 21)\end{array}$ & $\begin{array}{l}42.8 \% \\
(9 / 21)\end{array}$ & 0 \\
\hline \multicolumn{6}{|c|}{ Sureka control $n=24$} & 55 & NR & - & - & - & NR & NR & NR & NR & $\begin{array}{l}\text { All, but } \\
\text { excluded if } \\
\text { muscle not } \\
\text { present }\end{array}$ & $\begin{array}{l}54.16 \% \\
(13 / 24)\end{array}$ & $\begin{array}{l}45.8 \% \\
(11 / 2 \\
4)\end{array}$ & 0 \\
\hline
\end{tabular}


CUAJ - Review

Croghan et al

En bloc TURBT

\begin{tabular}{|c|c|c|c|c|c|c|c|c|c|c|c|c|c|c|c|c|c|c|}
\hline \multicolumn{6}{|c|}{ Statistical significance } & - & - & - & - & - & - & - & - & - & - & - & \multirow{2}{*}{$\begin{array}{l}- \\
36.3 \% \\
(33 / 9 \\
1) \\
\end{array}$} & \multirow{2}{*}{$\begin{array}{l}- \\
8.8 \% \\
(8 / 91)\end{array}$} \\
\hline $\begin{array}{l}\text { Kramer }^{42} \\
\text { (Monopol } \\
\text { ar Arm) }\end{array}$ & 2015 & 91 & $\begin{array}{l}\text { Monop } \\
\text { olar }\end{array}$ & Prosp. & No & 69 & $\begin{array}{l}78 \% \\
(71 / 9 \\
1)\end{array}$ & \multirow{2}{*}{$\begin{array}{l}26.3 \% \\
\text { of } \\
\text { electr } \\
\text { o- } \\
\text { cauter } \\
\text { y } \\
\text { switch } \\
\text { ed to } \\
\text { cTUR } \\
\text { BT }\end{array}$} & $<5 \mathrm{~cm}^{\wedge}$ & \multirow[b]{2}{*}{$\begin{array}{l}\text { Forceps } \\
\text { (occasionall } \\
\text { y specimen } \\
\text { bag) }\end{array}$} & NR & $\begin{array}{l}1.09 \% \\
(1 / 91)\end{array}$ & NR & \multirow[b]{2}{*}{$\begin{array}{l}3.9 \% \\
(6 / 156)\end{array}$} & \multirow[b]{2}{*}{$\begin{array}{l}96.2 \% \\
(150 / 156)\end{array}$} & $\begin{array}{l}54.9 \% \\
(50 / 91)\end{array}$ & & \\
\hline $\begin{array}{l}\text { Kramer }^{42} \\
\text { (Bipolar } \\
\text { Arm) }\end{array}$ & 2015 & 65 & Bipolar & Prosp. & No & 65.5 & $\begin{array}{l}83 \% \\
(54 / 6 \\
5)\end{array}$ & & $<5 \mathrm{~cm}^{\wedge}$ & & NR & $\begin{array}{l}\text { None } \\
0 / 65\end{array}$ & NR & & & $\begin{array}{l}50.7 \% \\
(33 / 65)\end{array}$ & $\begin{array}{l}44.62 \\
\% \\
(29 / 6 \\
5)\end{array}$ & $\begin{array}{l}4.61 \% \\
(3 / 65)\end{array}$ \\
\hline Hurle $^{27}$ & 2016 & 74 & $\begin{array}{l}\text { Energy } \\
\text { NR } \\
\text { (Collins } \\
\text { loop) }\end{array}$ & Prosp. & No & 71 & $\begin{array}{l}78.4 \% \\
(58 / 7 \\
4)\end{array}$ & $\begin{array}{l}0.97 \% \\
(1 / 103 \\
\text { tumo } \\
\text { Urs) } \\
\text { conve } \\
\text { rted }\end{array}$ & $3 \mathrm{~cm}$ & $\begin{array}{l}\text { Ellik } \\
\text { (laparoscop } \\
\text { ic grapsers } \\
\text { via } \\
\text { nephroscop } \\
\text { e for large) }\end{array}$ & NR & $\begin{array}{c}1.35 \% \\
(1 / 74)\end{array}$ & $\begin{array}{l}1.35 \% \\
(1 / 74)\end{array}$ & 0 & $\begin{array}{l}100 \% \\
(74 / 74)\end{array}$ & $\begin{array}{l}72.3 \% \\
(47 / 65)\end{array}$ & $\begin{array}{l}41.5 \% \\
(27 / 6 \\
5)\end{array}$ & $\mathrm{X}$ \\
\hline $\begin{array}{l}\text { Zhang } \\
\text { KY }^{28}\end{array}$ & 2017 & 40 & $\begin{array}{l}\text { Monop } \\
\text { olar } \\
\text { (Loop) }\end{array}$ & Retro. & Yes & 60.65 & $\begin{array}{l}87.5 \% \\
(35 / 4 \\
0)\end{array}$ & $\begin{array}{l}\text { Comb } \\
\text { inatio } \\
\mathrm{n} \\
\text { techni } \\
\text { que } \\
\text { for } \\
\text { large }\end{array}$ & $>3 \mathrm{~cm}$ & Ellik & GA & $\begin{array}{l}22.5 \% \\
(9 / 40)\end{array}$ & $\begin{array}{l}5 \% \\
(2 / 40)\end{array}$ & 0 & $\begin{array}{l}100 \% \\
(40 / 40)\end{array}$ & $\begin{array}{l}37.5 \% \\
(15 / 40)\end{array}$ & $\begin{array}{l}62.5 \% \\
(25 / 4 \\
0)\end{array}$ & None \\
\hline \multicolumn{6}{|c|}{ Zhang control $\mathrm{n}=50$} & & & & & & & & & & $54 \%(27 / 50)$ & & & \\
\hline \multicolumn{6}{|c|}{ RoB: in general $=$ Moderate; Re recurrence $=$ Serious } & 60.8 & $\begin{array}{l}76 \% \\
(38 / 5 \\
0)\end{array}$ & - & - & - & GA & $\begin{array}{l}4 \% \\
(2 / 50)\end{array}$ & $\begin{array}{l}8 \% \\
(4 / 50)\end{array}$ & 0 & $\begin{array}{l}\text { In specimen } \\
\text { (base cold } \\
\text { cup biopsies } \\
\text { separately) }\end{array}$ & $\begin{array}{l}54 \% \\
(27 / 50)\end{array}$ & $\begin{array}{l}46 \% \\
(23 / 5 \\
0)\end{array}$ & None \\
\hline \multicolumn{6}{|c|}{ Statistical Significance } & - & - & - & - & - & - & $\mathrm{p}=0.867$ & $\mathrm{p}=0.689$ & 0 & $\mathrm{p}<0.01$ & - & - & None \\
\hline
\end{tabular}


CUAJ - Review

Croghan et al

En bloc TURBT

\begin{tabular}{|c|c|c|c|c|c|c|c|c|c|c|c|c|c|c|c|c|c|c|}
\hline Balan $^{19}$ & 2018 & 45 & $\begin{array}{l}\begin{array}{l}\text { Bipolar } \\
\text { (plasma } \\
\text { button } \\
+ \text { loop) }\end{array} \\
\end{array}$ & $\mathrm{RCT}$ & Yes & 64.7 & NR & All & $<3 \mathrm{~cm}$ & NR & NR & $\begin{array}{l}11.1 \% \\
(5 / 45)\end{array}$ & NR & $\begin{array}{l}\text { NR; mean } \\
\mathrm{Hb} \text { drop } \\
0.28 \mathrm{~g} / \mathrm{dL}\end{array}$ & $100 \%$ & $\begin{array}{l}53.3 \% \\
(24 / 45)\end{array}$ & $\begin{array}{l}46.7 \% \\
(21 / 4 \\
5)\end{array}$ & None \\
\hline \multicolumn{6}{|c|}{ Balan control $\mathrm{n}=45$ (monopolar cTURBT) } & \multirow[b]{2}{*}{66.1} & & \multirow[b]{2}{*}{-} & \multirow[b]{2}{*}{ - } & & \multirow[b]{2}{*}{-} & \multirow[b]{2}{*}{$\begin{array}{r}4.4 \% \\
(2 / 45)\end{array}$} & \multirow[b]{2}{*}{ NR } & \multirow{2}{*}{$\begin{array}{l}\mathrm{NR} ; \\
\text { mean } \mathrm{Hb} \\
\text { drop } \\
0.76 \mathrm{~g} / \mathrm{dL}\end{array}$} & \multirow[b]{2}{*}{$100 \%$} & \multirow[b]{2}{*}{$\begin{array}{l}51.1 \% \\
(23 / 45)\end{array}$} & \multirow[b]{2}{*}{$\begin{array}{l}48.9 \% \\
(22 / 4 \\
5)\end{array}$} & \multirow[b]{2}{*}{ None } \\
\hline $\begin{array}{l}\text { RoB: in get } \\
\text { concerns }\end{array}$ & eral $=s$ & me c & rns; Re rec & urrence $=\varsigma$ & ome & & & & & & & & & & & & & \\
\hline \multicolumn{6}{|c|}{ Statistical significance } & - & - & - & - & & - & $\begin{array}{l}\mathrm{p}<0.05 \\
\sim\end{array}$ & - & $\mathrm{p}<0.05$ & No difference & - & - & - \\
\hline Zhang $\mathrm{J}^{20}$ & 2018 & 82 & $\begin{array}{l}\text { Bipolar } \\
\text { (plasma } \\
\text { button) }\end{array}$ & $\begin{array}{l}\text { Observ. } \\
\text { Unclear }\end{array}$ & No & 58.4 & $\begin{array}{l}74.4 \% \\
(61 / 8 \\
2) \\
\end{array}$ & NR & $<4 \mathrm{~cm}$ & Ellik & NR & None & None & None & $100 \%$ & 26 & 51 & 5 \\
\hline Huang $^{39}$ & 2020 & 12 & $\begin{array}{l}\text { Monop } \\
\text { olar } \\
\text { (loop) } \\
\end{array}$ & $\begin{array}{l}\text { Prosp. } \\
\text { Non- } \\
\text { Ran } \\
\end{array}$ & Yes & NR & $\begin{array}{l}75 \% \\
(9 / 12)\end{array}$ & All & $<3 \mathrm{~cm}$ & NR & NR & NR & NR & NR & NR & $6 / 12$ & $6 / 12$ & None \\
\hline \multicolumn{6}{|c|}{ Huang control $n=9$} & \multirow{2}{*}{ NR } & \multirow{2}{*}{$\begin{array}{l}77.8 \% \\
(7 / 9)\end{array}$} & & \multirow{2}{*}{-} & \multirow{2}{*}{-} & \multirow{2}{*}{-} & \multirow{2}{*}{-} & \multirow{2}{*}{-} & \multirow{2}{*}{ - } & \multirow{2}{*}{-} & \multirow{2}{*}{$6 / 9$} & \multirow{2}{*}{$3 / 9$} & \multirow{2}{*}{ None } \\
\hline RoB: in ger & eral $=1$ & odera & Re recurren & ce $=$ Seriou & & & & & & & & & & & & & & \\
\hline \multicolumn{6}{|c|}{ Statistical significance } & - & - & - & - & - & - & - & - & - & - & - & - & - \\
\hline Yang $\mathrm{Y}^{16}$ & 2020 & 26 & $\begin{array}{l}\text { Monop } \\
\text { olar }\end{array}$ & Retro. & No & 62.39 & $\begin{array}{l}80.7 \% \\
(21 / 2 \\
6) \\
\end{array}$ & All & $<3 \mathrm{~cm}$ & $\begin{array}{l}\text { Ellik, } \\
\text { occasionall } \\
\text { y forceps }\end{array}$ & $\begin{array}{l}\text { Spinal } \\
+ \text { +Epid } \\
\text { ural } \\
\end{array}$ & $\begin{array}{l}23 \% \\
(6 / 26)\end{array}$ & $\begin{array}{l}3.8 \% \\
(1 / 26)\end{array}$ & NR & $\begin{array}{r}88.5 \% \\
(23 / 26)\end{array}$ & $\begin{array}{l}42.3 \% \\
(11 / 26)\end{array}$ & $\begin{array}{l}57.7 \% \\
(15 / 2 \\
6) \\
\end{array}$ & $\mathrm{X}$ \\
\hline $\begin{array}{l}\text { Bangash }_{9}^{2} \\
\end{array}$ & 2020 & 41 & $\begin{array}{l}\text { Monop } \\
\text { olar } \\
\text { (Collins } \\
\text { knife) } \\
\end{array}$ & $\begin{array}{l}\text { Prosp. } \\
\text { Non- } \\
\text { Ran }\end{array}$ & Yes & 58.46 & $\begin{array}{l}82.9 \% \\
(34 / 4 \\
1)\end{array}$ & NR & $<3 \mathrm{~cm}$ & NR & NR & NR & $\begin{array}{l}\text { None } \\
(0 / 41)\end{array}$ & $\begin{array}{l}7.3 \% \\
(3 / 41) \\
\text { haematuri } \\
\mathrm{a} \\
\end{array}$ & $100 \%$ & $\begin{array}{r}48.8 \% \\
(20 / 41)\end{array}$ & $\begin{array}{l}51.2 \% \\
(21 / 4 \\
1) \\
\end{array}$ & $\begin{array}{l}46.3 \% \\
(19 / 4 \\
1) \\
\end{array}$ \\
\hline \multicolumn{6}{|c|}{ Bangash control $n=41$} & \multirow[b]{2}{*}{58.59} & \multirow[b]{2}{*}{ - } & \multirow[b]{2}{*}{ - } & Wr & & & & & & & & & \\
\hline RoB: in gel & eral $=1$ & odere & Re recurren & $c e=$ Mode & & & & & - & - & - & - & NR & $\begin{array}{l}9.75 \% \\
(4 / 41)\end{array}$ & $\begin{array}{r}56.1 \% \\
(23 / 41)\end{array}$ & $\begin{array}{r}46.3 \% \\
(19 / 41)\end{array}$ & $\begin{array}{l}53.7 \% \\
(22 / 4 \\
1)\end{array}$ & None \\
\hline Statistical s & gnifica & & & & & - & - & - & - & - & - & - & - & 0.68 & $<0.001$ & NS & NS & None \\
\hline
\end{tabular}


CUAJ - Review

Croghan et al

En bloc TURBT

\begin{tabular}{|c|c|c|c|c|c|c|c|c|c|c|c|c|c|c|c|c|c|c|}
\hline Miyake ${ }^{41}$ & 2020 & 12 & $\begin{array}{l}\text { Bipolar } \\
\text { (flat } \\
\text { loop) }\end{array}$ & $\begin{array}{l}\text { Prosp. } \\
\text { Non- } \\
\text { Ran }\end{array}$ & Yes & 76.5 & $\begin{array}{l}91.67 \\
\% \\
(11 / 1 \\
2) \\
\end{array}$ & All & $<2.5 \mathrm{~cm}$ & $\begin{array}{l}\text { Grasping } \\
\text { forceps }\end{array}$ & $\begin{array}{l}\text { Gener } \\
\text { al or } \\
\text { spinal }\end{array}$ & NR & $\begin{array}{l}8.34 \% \\
(1 / 12)\end{array}$ & NR & $\begin{array}{l}100 \% \\
(12 / 12)\end{array}$ & $\begin{array}{l}83.34 \% \\
(10 / 12)\end{array}$ & $\begin{array}{l}16.7 \% \\
(2 / 12)\end{array}$ & None \\
\hline \multicolumn{6}{|c|}{ Miyake control $\mathrm{n}=28$} & \multirow[b]{2}{*}{74.6} & \multirow{2}{*}{$\begin{array}{l}89.3 \% \\
(25 / 2 \\
8)\end{array}$} & \multirow[b]{2}{*}{ - } & \multirow[b]{2}{*}{ - } & \multirow[b]{2}{*}{ - } & & \multirow[b]{2}{*}{ NR } & \multirow[b]{2}{*}{0} & \multirow[b]{2}{*}{ NR } & \multirow[b]{2}{*}{ NR } & \multirow[b]{2}{*}{$21 / 28$} & \multirow[b]{2}{*}{$7 / 28$} & \multirow[b]{2}{*}{ None } \\
\hline RoB: in get & eral $=1$ & derat & Re recurren & $c e=\operatorname{Mod}$ & ate-Serious & & & & & & & & & & & & & \\
\hline \multicolumn{6}{|c|}{ Statistical Significance } & - & - & - & - & - & - & - & NS & & - & - & - & - \\
\hline Eissa $^{13}$ & 2020 & 50 & $\begin{array}{l}\text { Monop } \\
\text { olar } \\
\text { (bent } \\
\text { loop) }\end{array}$ & Retro. & No & 72.26 & $\begin{array}{l}80 \% \\
(40 / 5 \\
0)\end{array}$ & $\begin{array}{l}\text { All } \\
\text { but } \\
\text { this } \\
\text { was } \\
\text { ERBT } \\
\text { cohort }\end{array}$ & $2 \mathrm{~cm}$ & $\begin{array}{l}\text { Forceps or } \\
\text { Ellik }\end{array}$ & $\begin{array}{l}\text { Gener } \\
\text { al }\end{array}$ & NR & $\begin{array}{l}4 \% \\
(2 / 50)\end{array}$ & None & $\begin{array}{l}90 \% \\
(45 / 50)\end{array}$ & $\begin{array}{l}28 \% \\
(14 / 50)\end{array}$ & $\begin{array}{l}72 \% \\
(36 / 5 \\
0)\end{array}$ & $\mathrm{X}$ \\
\hline$\underset{8}{\text { Hameed }^{1}}$ & 2021 & 23 & $\begin{array}{l}\text { Zedd } \\
\text { Excisio } \\
\mathrm{n} \\
\text { Scissors } \\
\end{array}$ & Prosp. & No & 64 & $\begin{array}{l}69.6 \\
(16 / 2 \\
3)\end{array}$ & NR & $2.6 \mathrm{~cm}$ & $\begin{array}{l}3 \text { pronged } \\
\text { grasper or } \\
\text { Ellik }\end{array}$ & NR & 0 & 0 & 0 & $\begin{array}{l}91 \% \\
(21 / 23)\end{array}$ & $\begin{array}{l}35 \% \\
(8 / 23)\end{array}$ & $\begin{array}{l}57 \% \\
(13 / 2 \\
3)\end{array}$ & $\begin{array}{l}9 \% \\
(2 / 23)\end{array}$ \\
\hline $\begin{array}{l}\text { Yanagisa } \\
\mathbf{w a}^{21} \\
\wedge\end{array}$ & 2021 & 140 & $\begin{array}{l}\text { Bipolar } \\
\text { (needle } \\
\text { electrod } \\
\text { e) }\end{array}$ & $\begin{array}{l}\text { Prosp. } \\
\text { Non- } \\
\text { Ran }\end{array}$ & No & 72 & $\begin{array}{l}75 \% \\
(105 / \\
140)\end{array}$ & $\begin{array}{l}\text { All, } \\
\text { but en } \\
\text { bloc } \\
\text { cohort } \\
\text { studie } \\
\text { d }\end{array}$ & $<3 \mathrm{~cm}$ & $\begin{array}{l}\text { Biopsy } \\
\text { forceps }\end{array}$ & NR & $\begin{array}{l}0 \\
(\mathrm{n}=67 \\
\text { lateral) }\end{array}$ & $\begin{array}{l}0.71 \% \\
(1 / 140)\end{array}$ & $\begin{array}{l}1.42 \% \\
(2 / 140)\end{array}$ & $90 \%$ & $\begin{array}{l}66 \% \\
(93 / 140 \\
)\end{array}$ & $\begin{array}{l}34 \% \\
(47 / 1 \\
40)\end{array}$ & $\mathrm{X}$ \\
\hline $\operatorname{Teoh}^{40}$ & 2021 & 135 & $\begin{array}{l}\text { Mixed } \\
\text { mono/bi } \\
\text { polar } \\
\text { (loop) }\end{array}$ & $\begin{array}{l}\text { Prosp. } \\
\text { Non- } \\
\text { Ran }\end{array}$ & $\begin{array}{l}\text { Not } \\
\text { intention- } \\
\text { to-treat } \\
\text { (cases } \\
\text { converted } \\
\text { to } \\
\text { cTURBT } \\
\text { included) }\end{array}$ & 71.3 & $\begin{array}{l}71.1 \% \\
(96 / 1 \\
35)\end{array}$ & $\begin{array}{l}\begin{array}{l}94.3 \% \\
<1 \mathrm{~cm}\end{array} \\
82.2 \% \\
1.01- \\
2 \mathrm{~cm} \\
75 \% \\
2.01- \\
3 \mathrm{~cm} \\
29.6 \% \\
>3 \mathrm{~cm} \\
\end{array}$ & $\begin{array}{l}6 \mathrm{~cm} \\
(80 \% \\
\leq 3 \mathrm{~cm})\end{array}$ & NR & NR & NR & 0 & $\begin{array}{l}5.1 \% \\
(5 / 99)\end{array}$ & $80.8 \%$ & $65 \% * *$ & $\begin{array}{l}17.2 \% \\
* *\end{array}$ & $\mathrm{X}$ \\
\hline
\end{tabular}


CUAJ - Review

Croghan et al

En bloc TURBT

\begin{tabular}{|c|c|c|c|c|c|c|c|c|c|c|c|c|c|c|c|c|c|c|}
\hline Yasui $^{46}$ & 2021 & 61 & Bipolar & Retro. & No & 76 & $\begin{array}{l}83.6 \% \\
(51 / 6 \\
1)\end{array}$ & $\begin{array}{l}\text { NR } \\
\text { (ERB } \\
\text { T } \\
\text { cohort } \\
\text { ) }\end{array}$ & $\begin{array}{l}<3 \mathrm{~cm} \\
\text { majorit } \\
\mathrm{y} . \\
>3 \mathrm{~cm} \\
\text { cTURB } \\
\mathrm{T} \text { of } \\
\text { exo- } \\
\text { phytic } \\
\text { and } \\
\text { ERBT } \\
\text { of base. }\end{array}$ & NR & NR & NR & NR & NR & NR & $\mathrm{X}$ & $\begin{array}{l}100 \% \\
(61)- \\
\text { select } \\
\text { ed. } \\
\text { Stratif } \\
\text { ied } \\
\text { pT1 } \\
\text { a,b,c }\end{array}$ & $\mathrm{X}$ \\
\hline $\begin{array}{l}\text { Poletaje } \\
\mathbf{w}^{43}\end{array}$ & 2021 & 153 & $\begin{array}{l}\text { Mixed } \\
\text { (predo } \\
\text { minantl } \\
\text { y } \\
\text { monopo } \\
\text { lar) } \\
\text { Collins } \\
\text { knife or } \\
\text { resectio } \\
\text { n loop } \\
\end{array}$ & $\begin{array}{l}\text { Prosp. } \\
\text { Non- } \\
\text { Ran }\end{array}$ & Yes & 68 & $\begin{array}{l}76.5 \% \\
(117 / \\
153)\end{array}$ & $\begin{array}{l}\text { "very } \\
\text { scarce } \\
\text {," } \\
\text { exclu } \\
\text { ded } \\
\text { from } \\
\text { analys } \\
\text { is }\end{array}$ & $\leq 4 \mathrm{~cm}$ & NR & NR & NR & NR & NR & $\begin{array}{l}91.3 \% \\
(126 / 138) \\
\text { (propensity } \\
\text { score } \\
\text { matched) }\end{array}$ & $\begin{array}{l}61.4 \% \\
(94 / 153 \\
)^{* *}\end{array}$ & $\begin{array}{l}24.8 \% \\
(38 / 1 \\
53) \text { ** }\end{array}$ & $\begin{array}{l}3.9 \% \\
(6 / 15 \\
3) * *\end{array}$ \\
\hline \multicolumn{6}{|c|}{ Poletajew control n=274 } & & $73.4 \%$ & & & & & & & & & & $21.1 \%$ & $11.7 \%$ \\
\hline \multicolumn{6}{|c|}{ RoB: in general $=$ Moderate; Re recurrence $=$ Serious } & 69.5 & $\begin{array}{l}(201 / \\
274)\end{array}$ & & & & - & - & - & - & $(95 / 138)$ & $\begin{array}{l}(126 / 27 \\
4) \\
\end{array}$ & $\begin{array}{l}(58 / 2 \\
74) \\
\end{array}$ & $\begin{array}{l}(32 / 2 \\
74) \\
\end{array}$ \\
\hline \multicolumn{6}{|c|}{ Statistical significance } & NS & NS & -1 & - & - & - & - & - & - & $\mathrm{P}<0.001$ & - & - & - \\
\hline
\end{tabular}

${ }^{\wedge}$ Larger tumors were divided prior to extraction however ( $3 \mathrm{~cm}$ cut off for Kramer). ${ }^{*}$ Each individual lesion analysed rather than each patient hence bigger denominator. Lower rates of obturator reflex activation, however breakdown of lateral wall location unclear. ${ }^{* *}$ Remainder T0. ^^Additional papers by same author referenced but not tabulated as patient cohorts overlapping. non-ran: non-randomized; NR: not reported; observ: observational; prosp: prospective; RCT: randomized controlled trial; RoB: risk of bias; X: excluded. 


\begin{tabular}{|c|c|c|c|c|c|c|c|c|c|c|c|c|c|c|c|c|c|c|c|}
\hline Author & Laser & Yr & $\begin{array}{l}\text { ER } \\
\text { BT } \\
\wedge \\
\text { n }\end{array}$ & $\begin{array}{l}\text { Study } \\
\text { Desig } \\
\text { n }\end{array}$ & $\begin{array}{l}\text { cTURB } \\
\text { T } \\
\text { Control } \\
\text { Group? }\end{array}$ & $\begin{array}{l}\text { Age } \\
\text { (Av } \\
\text { g) }\end{array}$ & $\begin{array}{l}\text { Male } \\
\%\end{array}$ & $\begin{array}{l}\text { Laser } \\
\text { para- } \\
\text { meter } \\
\text { s }\end{array}$ & $\begin{array}{l}\text { Feasibilit } \\
\mathbf{y}\end{array}$ & $\begin{array}{l}\text { Max } \\
\text { tumor } \\
\text { size }\end{array}$ & $\begin{array}{l}\text { Extractio } \\
\text { n }\end{array}$ & $\begin{array}{l}\text { Anesthes } \\
\text { ia }\end{array}$ & $\begin{array}{l}\text { Obturato } \\
\text { r reflex }\end{array}$ & $\begin{array}{l}\text { Bladder } \\
\text { perforati } \\
\text { on }\end{array}$ & $\begin{array}{l}\text { Signific } \\
\text { ant } \\
\text { bleedin } \\
g^{*}\end{array}$ & $\begin{array}{l}\text { Muscul } \\
\text { aris } \\
\text { propria } \\
\text { identifi } \\
\text { ed in } \\
\text { specim } \\
\text { en? }\end{array}$ & pTa & pT1 & $\geq \mathbf{p T 2}$ \\
\hline \multicolumn{20}{|c|}{ Holmium laser } \\
\hline Kramer & $\begin{array}{l}\text { Holmi } \\
\text { um } \\
\text { arm } \\
\end{array}$ & $\begin{array}{l}201 \\
5\end{array}$ & 50 & Prosp. & No & 62.2 & $\begin{array}{l}72 \% \\
(36 / 50)\end{array}$ & $\begin{array}{l}1-2 \mathrm{~J} \\
15- \\
30 \mathrm{~Hz}\end{array}$ & $\begin{array}{l}98 \% \\
(49 / 50)^{*}\end{array}$ & $<4 \mathrm{~cm}$ & $\begin{array}{l}\text { Specimen } \\
\text { retrieval } \\
\text { bags in } \\
\text { some }\end{array}$ & NR & 0 & NR & $\begin{array}{l}2 \% \\
(1 / 50)^{*}\end{array}$ & $\begin{array}{l}50 / 50 \\
(100 \%)\end{array}$ & $\begin{array}{l}58 \% \\
(29 / 5 \\
0)\end{array}$ & $\begin{array}{l}42 \% \\
(21 / 50)\end{array}$ & 0 \\
\hline $\begin{array}{l}\text { Mahesh } \\
\text {-wari }\end{array}$ & $\begin{array}{l}\text { Holmi } \\
\text { um }\end{array}$ & $\begin{array}{l}202 \\
0\end{array}$ & 67 & Retro. & No & 57.8 & $\begin{array}{l}77.6 \% \\
(52 / 67)\end{array}$ & $\begin{array}{l}550 \mathrm{u} \\
1-2 \mathrm{~J} \\
40- \\
50 \mathrm{~Hz}\end{array}$ & All & $4 \mathrm{cn}$ & Ellik & $\begin{array}{l}\text { General } \\
\text { or } \\
\text { regional }\end{array}$ & 0 & 0 & $\begin{array}{l}5.97 \% \\
(4 / 67)\end{array}$ & $\begin{array}{l}57 / 67 \\
(85 \%)\end{array}$ & $\begin{array}{l}82 \% \\
(55 / 6 \\
7)\end{array}$ & $\begin{array}{l}17.9 \% \\
(12 / 67)\end{array}$ & $\mathrm{X}$ \\
\hline $\begin{array}{l}\text { Hashe } \\
\mathrm{m}^{14}\end{array}$ & $\begin{array}{l}\text { Holmi } \\
\text { um }\end{array}$ & $\begin{array}{l}202 \\
0\end{array}$ & 50 & $\mathrm{RCT}$ & Yes & 60.4 & $\begin{array}{l}74 \% \\
(37 / 50)\end{array}$ & $\begin{array}{l}1-2 \mathrm{~J} \\
10- \\
15 \mathrm{~Hz} \\
10- \\
30 \mathrm{~W}\end{array}$ & All & $<5 \mathrm{~cm}$ & $\begin{array}{l}\text { Cold- } \\
\text { crown } \\
\text { loop }\end{array}$ & NR & 0 & 0 & 0 & $\begin{array}{l}98 \% \\
(49 / 50)\end{array}$ & $\begin{array}{l}4.5 \% \\
(2 / 50)\end{array}$ & $\begin{array}{l}95.5 \% \\
(42 / 50)\end{array}$ & $\begin{array}{l}4 \% \\
(2 / 50)\end{array}$ \\
\hline \multicolumn{6}{|c|}{ Hashem control $n=50$} & & & & & & & & & & & & & & \\
\hline \multicolumn{6}{|c|}{$\begin{array}{l}\text { RoB: in general = Low; Re recurrence }=\text { Some } \\
\text { concerns }\end{array}$} & 61.1 & $\begin{array}{l}78 \% \\
(39 / 50)\end{array}$ & & & & & - & $\begin{array}{l}24 \% \\
(12 / 50)\end{array}$ & $\begin{array}{l}12 \% \\
(6 / 50)\end{array}$ & $\begin{array}{l}6 \% \\
(3 / 50)\end{array}$ & $\begin{array}{l}62 \% \\
(31 / 50)\end{array}$ & $\begin{array}{l}6.1 \% \\
(3 / 50)\end{array}$ & $\begin{array}{l}93.9 \% \\
(46 / 50)\end{array}$ & 0 \\
\hline \multicolumn{6}{|c|}{ Statistical significance } & $-\quad$ & - & - & - & - & - & - & $<0.001$ & - & NS & $<0.001$ & NS & NS & NS \\
\hline \multicolumn{20}{|c|}{ Green light laser } \\
\hline $\mathrm{He}^{35}$ & $\begin{array}{l}\text { Green } \\
\text { Light } \\
\text { (KTP) } \\
\text { front- } \\
\text { firing }\end{array}$ & $\begin{array}{l}201 \\
4\end{array}$ & 45 & Retro. & No & 57.8 & NR & $\begin{array}{l}0.6 \mathrm{~J} \\
50 \mathrm{~Hz} \\
(30 \mathrm{~W} \\
)\end{array}$ & $\begin{array}{l}\text { All, but } \\
\text { wire loop } \\
\text { coagulati } \\
\text { on } \\
\text { required } \\
\text { in } 1\end{array}$ & $3 \mathrm{~cm}$ & Ellik & $\begin{array}{l}\text { Continuo } \\
\text { us } \\
\text { epidural }\end{array}$ & 0 & 0 & $\begin{array}{l}\text { Irrigatio } \\
\mathrm{n} \mathrm{n}=1 \\
\mathrm{Hb} \\
\text { mean } \\
1.1 \mathrm{~g} / \mathrm{dL} \\
\text { decreas } \\
\mathrm{e}\end{array}$ & $\begin{array}{l}100 \% \\
(45 / 45)\end{array}$ & $\begin{array}{l}60 \% \\
(27 / 4 \\
5)\end{array}$ & $\begin{array}{l}33.4 \% \\
(15 / 45)\end{array}$ & $\begin{array}{l}6.67 \% \\
(3 / 45)\end{array}$ \\
\hline Chen $^{34}$ & $\begin{array}{l}\text { Green } \\
\text { Light } \\
6 \mathrm{~F}\end{array}$ & $\begin{array}{l}201 \\
6\end{array}$ & 83 & Prosp. & Yes & $\begin{array}{l}63.4 \\
3\end{array}$ & $\begin{array}{l}72.3 \% \\
(60 / 83)\end{array}$ & $\begin{array}{l}120- \\
160 \mathrm{~W} \\
\text { (cut) }\end{array}$ & NR & $3 \mathrm{~cm}$ & Ellik & $\begin{array}{l}\text { Continuo } \\
\text { us } \\
\text { epidural }\end{array}$ & 0 & 0 & $\begin{array}{l}\mathrm{NR} \\
\text { (less } \mathrm{Hb} \\
\text { drop }\end{array}$ & NR & $\begin{array}{l}84.3 \% \\
(70 / 8 \\
3)\end{array}$ & $\begin{array}{l}15.6 \% \\
(13 / 83)\end{array}$ & 0 \\
\hline
\end{tabular}


CUAJ - Review

Croghan et al

En bloc TURBT

\begin{tabular}{|c|c|c|c|c|c|c|c|c|c|c|c|c|c|c|c|c|c|c|c|}
\hline & $\begin{array}{l}\text { side- } \\
\text { firing }\end{array}$ & & & & & & & $\begin{array}{l}30- \\
50 \mathrm{~W} \\
\text { (coag) }\end{array}$ & & & & & & & \multirow{3}{*}{$\begin{array}{l}\text { with } \\
\text { LASER } \\
0.87 \text { vs } \\
1 \mathrm{~g} / \mathrm{dL})\end{array}$} & & & & \\
\hline \multicolumn{6}{|c|}{ Chen control $n=75$} & \multirow[b]{2}{*}{$\begin{array}{l}65.3 \\
1\end{array}$} & \multirow[b]{2}{*}{$\begin{array}{l}68 \% \\
(51 / 75)\end{array}$} & \multirow[t]{2}{*}{ 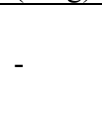 } & \multirow[b]{2}{*}{-} & \multirow[b]{2}{*}{ - } & \multirow[b]{2}{*}{ 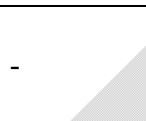 } & & \multirow[b]{2}{*}{$\begin{array}{l}12 \% \\
(9 / 75)\end{array}$} & \multirow[b]{2}{*}{$\begin{array}{l}2.67 \% \\
(2 / 75)\end{array}$} & & \multirow[b]{2}{*}{ NR } & \multirow{2}{*}{\begin{tabular}{|l|}
$85.3 \%$ \\
$(64 / 7$ \\
$5)$
\end{tabular}} & \multirow[b]{2}{*}{$\begin{array}{l}14.7 \% \\
(11 / 75)\end{array}$} & \multirow[b]{2}{*}{0} \\
\hline $\begin{array}{l}\text { RoB: in } \\
\text { Moderate }\end{array}$ & eneral $=$ & Low-m & derate & Re recu & rence $=$ & & & & & & & & & & & & & & \\
\hline \multicolumn{6}{|c|}{ Statistical significance } & - & - & - & - & - & & - & 0.001 & NS & - & - & - & - & - \\
\hline Cheng ${ }^{36}$ & $\begin{array}{l}\text { Green } \\
\text { Light } \\
\text { front- } \\
\text { firing }\end{array}$ & $\begin{array}{l}201 \\
7\end{array}$ & 34 & Retro. & Yes & $\begin{array}{l}59.4 \\
1\end{array}$ & $\begin{array}{l}82.4 \% \\
(28 / 34)\end{array}$ & $\begin{array}{l}120 \\
\mathrm{~W}\end{array}$ & NR & $3 \mathrm{~cm}$ & Ellik & $\begin{array}{l}\text { Spinal / } \\
\text { Epidural }\end{array}$ & 0 & NR & NR & $\begin{array}{l}97 \% \\
(33 / 34)\end{array}$ & $\begin{array}{l}41.2 \% \\
(14 / 3 \\
4) \\
\end{array}$ & $\begin{array}{l}16 \\
(47.06 \\
\%)\end{array}$ & $\begin{array}{l}4 \\
(11.76 \\
\%)\end{array}$ \\
\hline \multicolumn{6}{|c|}{ Cheng control $\mathrm{n}=30$} & \multirow[b]{2}{*}{$\begin{array}{l}63.1 \\
3\end{array}$} & \multirow[b]{2}{*}{$\begin{array}{l}90 \% \\
(27 / 30)\end{array}$} & & & & \multirow{3}{*}{$\begin{array}{l}- \\
- \\
- \\
\end{array}$} & & \multirow[b]{2}{*}{10} & \multirow[b]{2}{*}{ NR } & \multirow[b]{2}{*}{ NR } & \multirow[b]{2}{*}{$\begin{array}{l}80 \% \\
(24 / 30)\end{array}$} & \multirow{2}{*}{\begin{tabular}{|l|}
43.33 \\
$\%$ \\
$(13 / 3$ \\
$0)$ \\
\end{tabular}} & \multirow[b]{2}{*}{$\begin{array}{l}50 \% \\
(15 / 30)\end{array}$} & \multirow[b]{2}{*}{\begin{tabular}{|c|}
$6.7 \%$ \\
$(2 / 30)$
\end{tabular}} \\
\hline RoB: in & eneral $=$ & Moder & e; Re & ecurrenc & $=\mathrm{NA}$ & & & & & & & & & & & & & & \\
\hline \multicolumn{6}{|c|}{ Statistical significance } & - & - & - & - & - & & - & $\mathrm{p}<0.001$ & - & - & $\mathrm{p}=0.04$ & NS & NS & NS \\
\hline Liang $^{52}$ & $\begin{array}{l}\text { Green } \\
\text { Light } \\
\text { (KTP) } \\
\text { front- } \\
\text { firing }\end{array}$ & $\begin{array}{l}201 \\
9\end{array}$ & 88 & Retro. & Yes & 58 & $\begin{array}{c}88.6 \% \\
(78 / 88)\end{array}$ & $\begin{array}{l}0.6 \mathrm{~J} \\
50 \mathrm{~Hz} \\
(30 \mathrm{~W}\end{array}$ & NR & NR & NR & NR & NR & NR & NR & $\begin{array}{l}30.7 \% \\
(27 / 88)\end{array}$ & $\begin{array}{l}33 \% \\
(29 / 8 \\
8)\end{array}$ & $\begin{array}{l}67 \% \\
(59 / 88)\end{array}$ & 0 \\
\hline \multicolumn{6}{|c|}{ Liang control $n=70$} & & & & & & & +2 & & & & $11.4 \%$ & $47.1 \%$ & $52.9 \%$ & \\
\hline RoB: in & eneral $=$ & Low; F & recur & ence $=N$ & & - & - & - & - & - & - & - & - & - & - & $(8 / 70)$ & $\begin{array}{l}(33 / 7 \\
0)\end{array}$ & $(37 / 70)$ & 0 \\
\hline Statistica & signific & & & & & - & - & - & - & - & - & - & - & - & - & $\begin{array}{l}\text { Signific } \\
\text { ant }\end{array}$ & NS & NS & - \\
\hline $\mathrm{Fan}^{30}$ & $\begin{array}{l}\text { Green } \\
\text {-light } \\
\text { Front } \\
\text { firing }\end{array}$ & $\begin{array}{l}202 \\
1\end{array}$ & 116 & RCT & Yes & 60 & $\begin{array}{l}83.2 \% \\
(96 / 116 \\
)^{2}\end{array}$ & $\begin{array}{l}532 \mathrm{n} \\
\mathrm{m} \\
0.6 \mathrm{~J} \mathrm{x} \\
50 \mathrm{~Hz} \\
(30 \mathrm{~W} \\
)\end{array}$ & $\begin{array}{l}\text { Appears } \\
\text { all }\end{array}$ & $<3 \mathrm{~cm}$ & $\begin{array}{l}\text { Via } \\
\text { sheath } \\
\text { /resection } \\
\text { loop/End } \\
\text { obag }\end{array}$ & NR & 0 & 0 & $\begin{array}{l}\text { NR } \\
\text { (less } \\
\text { EBL } \\
\text { with } \\
\text { Laser) }\end{array}$ & $\begin{array}{l}89.7 \% \\
(104 / 11 \\
6)\end{array}$ & $\begin{array}{l}78.5 \% \\
(91 / 1 \\
16)\end{array}$ & $\begin{array}{l}21.5 \% \\
(25 / 116 \\
)\end{array}$ & $\mathrm{X}$ \\
\hline Fan cont & $\mathrm{oln}=11$ & & & & & & $74 \%$ & & & & & & & & & $71.8 \%$ & $88.9 \%$ & $11.1 \%$ & \\
\hline $\begin{array}{l}\text { RoB: in } \\
\text { Some co }\end{array}$ & $\begin{array}{l}\text { eneral }= \\
\text { cerns }\end{array}$ & some & ncern & ; Re rect & rence $=$ & 57 & )$^{(87 / 117}$ & & - & - & - & - & $(9 / 117)$ & $\begin{array}{l}0.9 \% \\
(1 / 117)\end{array}$ & - & )$^{(84 / 117}$ & $\begin{array}{l}(104 / \\
117)\end{array}$ & )$^{(13 / 117}$ & - \\
\hline Statistica & signific & & & & & NS & - & - & - & - & - & - & 0.002 & NS & - & $<0.005$ & 0.031 & & - \\
\hline
\end{tabular}


CUAJ - Review

\begin{tabular}{|c|c|c|c|c|c|c|c|c|c|c|c|c|c|c|c|c|c|c|c|}
\hline Muto $^{23}$ & $\begin{array}{l}\text { Thuli } \\
\text { um- } \\
\text { YAG }\end{array}$ & $\begin{array}{l}201 \\
4\end{array}$ & 55 & Prosp. & No & 68 & $\begin{array}{l}89 \% \\
(49 / 55)\end{array}$ & $\begin{array}{l}800 \mathrm{n} \\
\mathrm{m} \\
30 \mathrm{~W} \\
\text { contin } \\
\text { uous } \\
\text { wave } \\
\text { (20W } \\
\text { pulse } \\
\text { d- } \\
\text { wave } \\
\text { for } \\
\text { coag) }\end{array}$ & All & $4.5 \mathrm{~cm}^{\wedge}$ & Grasper & Epidural & 0 & 0 & 0 & $\begin{array}{l}100 \% \\
(55 / 55)\end{array}$ & $\begin{array}{l}56.4 \% \\
(31 / 5 \\
5)\end{array}$ & $\begin{array}{r}32.7 \% \\
(18 / 55)\end{array}$ & $\begin{array}{l}10.9 \% \\
(6 / 55)\end{array}$ \\
\hline $\begin{array}{l}\text { Kramer } \\
42\end{array}$ & $\begin{array}{l}\text { Thuli } \\
\text { um } \\
\text { arm }\end{array}$ & $\begin{array}{l}201 \\
5\end{array}$ & 15 & Prosp. & No & 69.4 & $\begin{array}{l}80 \% \\
(12 / 15)\end{array}$ & $\begin{array}{l}550 \mathrm{u} \\
5-15 \\
\mathrm{~W}\end{array}$ & * & $<4 \mathrm{~cm}^{\wedge}$ & $\begin{array}{l}\text { Specimen } \\
\text { retrieval } \\
\text { bags in } \\
\text { some }\end{array}$ & NR & 0 & NR & * & $\begin{array}{l}100 \% \\
(15 / 15)\end{array}$ & $\begin{array}{l}66.7 \% \\
(10 / 1 \\
5)\end{array}$ & $\begin{array}{l}33.3 \% \\
(5 / 15)\end{array}$ & 0 \\
\hline $\begin{array}{l}\text { Migliar } \\
i^{48}\end{array}$ & $\begin{array}{l}\text { Thuli } \\
\text { um }\end{array}$ & $\begin{array}{l}201 \\
5\end{array}$ & 58 & $\begin{array}{l}\text { Prosp. } \\
\text { Non- } \\
\text { Ran } \\
\text { (retro } \\
\text { contro } \\
\text { 1) }\end{array}$ & Yes & 71 & $\begin{array}{l}70.7 \% \\
(41 / 58)\end{array}$ & $\begin{array}{l}\text { Conti } \\
\text { nuous } \\
\text { wave } \\
30 \mathrm{~W} \text {. } \\
1470 \mathrm{n} \\
\mathrm{m} \\
\text { Diode } \\
\text { for } \\
\text { coagu } \\
\text { lation } \\
\text { at } \\
20 \mathrm{~W}\end{array}$ & NR & $4.5 \mathrm{~cm}$ & $\begin{array}{l}\text { Via } \\
\text { sheath } \\
\text { with loop }\end{array}$ & Spinal & 0 & 0 & 0 & $\begin{array}{l}100 \% \\
(58 / 58)\end{array}$ & $\begin{array}{l}56.4 \% \\
(30 / 5 \\
8)\end{array}$ & $\begin{array}{r}32.7 \% \\
(23 / 58)\end{array}$ & $\begin{array}{l}10.9 \% \\
(5 / 58)\end{array}$ \\
\hline \multicolumn{6}{|c|}{ Migliari control $n=61$} & & & & & & & & & & & $\begin{array}{l}91.8 \% \\
(56 / 61)\end{array}$ & & & \\
\hline \multicolumn{6}{|c|}{$\begin{array}{l}\text { RoB: in general = Low-moderate; Re recurrence = } \\
\text { N/A }\end{array}$} & 72.5 & $\begin{array}{l}73.8 \% \\
(45 / 61)\end{array}$ & - & - & - & - & - & 8 & $\mathrm{NR}$ & $\begin{array}{l}3.27 \% \\
(2 / 61)\end{array}$ & $\begin{array}{l}\text { (3 not } \\
\text { valuabl } \\
\text { e due } \\
\text { themal } \\
\text { artifact) }\end{array}$ & - & - & - \\
\hline \multicolumn{6}{|c|}{ Statistical signficance } & - & - & $-\quad$ & - & - & - & - & NR & - & & $\mathrm{NR}$ & - & - & - \\
\hline Zhang $^{24}$ & $\begin{array}{l}\text { Thuli } \\
\text { um } \\
\text { Vela }\end{array}$ & $\begin{array}{l}201 \\
6\end{array}$ & 38 & $\begin{array}{l}\text { Prosp } \\
\text { s. }\end{array}$ & No & 62 & $\begin{array}{l}81.6 \% \\
(31 / 38)\end{array}$ & $\begin{array}{l}1.94 \mathrm{u} \\
\mathrm{m}\end{array}$ & All & $3 \mathrm{~cm}$ & $\begin{array}{l}\text { Sheath or } \\
\text { grasper }\end{array}$ & General & NR & 0 & 0 & $\begin{array}{l}100 \% \\
(38 / 38)\end{array}$ & $\begin{array}{l}39.5 \% \\
(15 / 3 \\
8) \\
\end{array}$ & $\begin{array}{l}57.9 \% \\
(22 / 38) \\
\end{array}$ & $\begin{array}{l}2.63 \% \\
(1 / 38) \\
\end{array}$ \\
\hline
\end{tabular}

Croghan et al

\section{En bloc TURBT}


CUAJ - Review

\begin{tabular}{|c|c|c|c|c|c|c|c|c|c|c|c|c|c|c|c|c|c|c|c|}
\hline & & & & & & & & \begin{tabular}{|l}
$600 \mathrm{u}$ \\
$\mathrm{m}$ \\
fibre \\
$50 \mathrm{~W}$ \\
\end{tabular} & & & & & & & & & & & \\
\hline $\mathrm{Xu} \mathrm{H}{ }^{12}$ & $\begin{array}{l}\text { Thuli } \\
\text { um } \\
\text { Vela }\end{array}$ & $\begin{array}{l}201 \\
8\end{array}$ & 26 & Retro. & Yes & 55.9 & $\begin{array}{l}92.3 \% \\
(24 / 26)\end{array}$ & $\begin{array}{l}1.9 \mathrm{um} \\
30 \mathrm{~W}\end{array}$ & NR & $4.5 \mathrm{~cm}$ & $\begin{array}{l}\text { Sheath or } \\
\text { with loop }\end{array}$ & General & 0 & 0 & 0 & $\begin{array}{l}100 \% \\
(30 / 30) \\
\text { on } \\
\text { initial } \\
\text { analysis }\end{array}$ & $\begin{array}{l}33.34 \\
\% \\
(10 / 3 \\
0)\end{array}$ & $\begin{array}{l}40 \% \\
(12 / 30)\end{array}$ & $\mathrm{X}$ \\
\hline \multicolumn{6}{|c|}{$\mathrm{Xu}$ control $\mathrm{n}=44$} & \multirow[b]{2}{*}{59.7} & \multirow[b]{2}{*}{$\begin{array}{l}79.5 \% \\
(35 / 44)\end{array}$} & \multirow[b]{2}{*}{-} & \multirow[b]{2}{*}{ - } & \multirow[b]{2}{*}{-} & & \multirow[b]{2}{*}{-} & \multirow[b]{2}{*}{$\begin{array}{l}16 \% \\
(7 / 44)\end{array}$} & \multirow[b]{2}{*}{$\begin{array}{l}6.8 \% \\
(3 / 44)\end{array}$} & \multirow[b]{2}{*}{0} & \multirow{2}{*}{$\begin{array}{l}69.8 \% \\
(44 / 63) \\
\text { On } \\
\text { initial } \\
\text { analysis } \\
\text { (exclud } \\
\text { ed w/o } \\
\text { muscle) }\end{array}$} & \multirow[b]{2}{*}{$\begin{array}{l}56.8 \% \\
(25 / 4 \\
4)\end{array}$} & \multirow[b]{2}{*}{$\begin{array}{l}36.36 \% \\
(16 / 44)\end{array}$} & \multirow[b]{2}{*}{$\mathrm{X}$} \\
\hline $\begin{array}{l}\text { RoB: in } \\
\text { Serious }\end{array}$ & eneral $=$ & Moder & te; Re r & ecurrence & & & & & & & & & & & & & & & \\
\hline \multicolumn{6}{|c|}{ Statistical significance } & - & - & - & - & - & - & - & - & - & - & $\mathrm{P}=0.04$ & - & - & - \\
\hline $\mathrm{Li}^{37}$ & $\begin{array}{l}\text { Thuli } \\
\text { um }\end{array}$ & $\begin{array}{l}201 \\
8\end{array}$ & 136 & Retro. & $\begin{array}{l}\begin{array}{l}\text { Yes } \\
\text { (plasma } \\
- \\
\text { kinetic) }\end{array} \\
\end{array}$ & NR & $\begin{array}{l}80.9 \% \\
(110 / 13 \\
6)\end{array}$ & $\begin{array}{l}550 \mathrm{u} \\
\mathrm{m} \\
1.5 \mathrm{~J} \\
20 \mathrm{~Hz} \\
30 \mathrm{~W} \\
\end{array}$ & & $<3.5 \mathrm{~cm}$ & Ellik & Spinal & 0 & 0 & 0 & $\begin{array}{l}95.6 \% \\
(130 / 13 \\
6)\end{array}$ & NR & NR & NR \\
\hline \multicolumn{6}{|c|}{ Li control $n=120$} & NR & $\begin{array}{l}81.7 \% \\
(98 / 120 \\
\end{array}$ & & & & & - & 4 & 1 & $\begin{array}{l}1.67 \% \\
(2 / 120)\end{array}$ & $\begin{array}{l}85.8 \% \\
(103 / 12 \\
0)\end{array}$ & NR & NR & NR \\
\hline \multicolumn{6}{|c|}{ Statistical significance } & - & - & - & - & - & - & - & 0.032 & NS & NS & $\begin{array}{l}\mathrm{P}=0.00 \\
6\end{array}$ & - & - & - \\
\hline $\begin{array}{l}\text { Xu S } \\
2 u m\end{array}$ & $\begin{array}{l}\text { Thuli } \\
\text { um }\end{array}$ & $\begin{array}{l}202 \\
0\end{array}$ & 141 & Retro. & No & 67 & $\begin{array}{l}81.6 \% \\
(115 / 14 \\
1)\end{array}$ & $\begin{array}{l}1.5 \mathrm{~J} \\
20 \mathrm{~Hz} \\
30 \mathrm{~W}\end{array}$ & NR & $4 \mathrm{~cm}$ & Ellik^ & NR & NR & $\begin{array}{l}1.4 \% \\
(2 / 141)\end{array}$ & NR & $\begin{array}{l}100 \% \\
(141 / 14 \\
1)\end{array}$ & $\begin{array}{l}70.2 \% \\
(99 / 1 \\
41)\end{array}$ & $\begin{array}{l}29.7 \% \\
(42 / 141\end{array}$ & $\mathrm{X}$ \\
\hline $\mathrm{Liu}^{31}$ & $\begin{array}{l}\text { Thuli } \\
\text { um }\end{array}$ & $\begin{array}{l}202 \\
1\end{array}$ & 134 & Retro. & Yes & 61.5 & $\begin{array}{l}75.4 \% \\
(101 / 13 \\
4)\end{array}$ & $30 \mathrm{~W}$ & NR & $<3 \mathrm{~cm}$ & $\begin{array}{l}\text { Via } \\
\text { sheath }\end{array}$ & GA & 0 & 0 & 0 & $\begin{array}{l}97.4 \% \\
(4 \\
\text { exclude } \\
\text { d due } \\
\text { quality) }\end{array}$ & $\begin{array}{l}53.7 \% \\
(72 / 1 \\
34)\end{array}$ & $\begin{array}{l}36.6 \% \\
(49 / 134 \\
)\end{array}$ & $\mathrm{X}$ \\
\hline \multicolumn{6}{|c|}{$\begin{array}{l}\text { Liu control } \mathrm{n}=152 \\
\text { (cTURBT electrocautery. Small lesions resected en } \\
\text { bloc with loop). }\end{array}$} & 60.3 & $\begin{array}{l}73 \% \\
(111 / 12 \\
5)\end{array}$ & - & - & - & - & GA & $\begin{array}{l}15.8 \% \\
(24 / 152) \\
\end{array}$ & $\begin{array}{l}5.9 \% \\
(9 / 152)\end{array}$ & $\begin{array}{l}2 \% \\
(3 / 152)\end{array}$ & $\begin{array}{l}87.6 \% \\
(23 \\
\text { exclude }\end{array}$ & $\begin{array}{l}57.2 \% \\
(87 / 1 \\
52)\end{array}$ & $\begin{array}{l}31.6 \% \\
(48 / 152 \\
\end{array}$ & $\mathrm{X}$ \\
\hline
\end{tabular}

C 2021 Canadian Urological Association

Croghan et al

En bloc TURBT 
En bloc TURBT

\begin{tabular}{|c|c|c|c|c|c|c|c|c|c|c|c|c|c|c|c|c|c|c|c|}
\hline \multicolumn{6}{|c|}{$\begin{array}{l}\text { RoB: in general = Moderate; Re recurrence }= \\
\text { Moderate-Serious }\end{array}$} & & & & & & & & & & & $\begin{array}{l}\mathrm{d} \text { due } \\
\text { quality) }\end{array}$ & & & \\
\hline \multicolumn{6}{|c|}{ Statistical significance } & NS & NS & - & - & - & - & & $<0.001$ & 0.012 & $0.267 * *$ & 0.001 & NS & NS & - \\
\hline Yang $^{25}$ & $\begin{array}{l}\text { Thuli } \\
\text { um }\end{array}$ & $\begin{array}{l}202 \\
1\end{array}$ & 235 & Retro. & $\begin{array}{l}\text { No } \\
\text { cTURB } \\
\mathrm{T} \\
\text { control }\end{array}$ & 65.7 & $\begin{array}{l}79.1 \% \\
(186 / 23 \\
5)\end{array}$ & NR & $\begin{array}{l}98 \% \\
(249 / 254 \\
\text { original } \\
\text { populatio } \\
\text { n) }\end{array}$ & $3 \mathrm{~cm}$ & $\begin{array}{l}\text { Ellik or } \\
\text { laparosco } \\
\text { pic } \\
\text { forceps }\end{array}$ & $\begin{array}{l}\text { Spinal/epi } \\
\text { dural }\end{array}$ & 0 & 0 & NR & $\begin{array}{l}\begin{array}{l}\text { Muscle } \\
=\end{array} \\
\text { Inclusio } \\
\mathrm{n} \\
\text { criterio } \\
\mathrm{n} \text {, but } \\
\text { appears } \\
\text { none of } \\
254 \\
\text { exclude } \\
\mathrm{d} \text { on } \\
\text { this } \\
\text { basis. }\end{array}$ & $\begin{array}{l}81.7 \% \\
(192 / \\
235)\end{array}$ & $\begin{array}{l}18.3 \% \\
(43 / 235 \\
)\end{array}$ & $\mathrm{X}$ \\
\hline \multicolumn{20}{|c|}{ Other lasers } \\
\hline Chen $^{49}$ & $\begin{array}{l} \\
\text { Micro } \\
\mathrm{n} \\
\end{array}$ & $\begin{array}{l}201 \\
5\end{array}$ & 71 & $\mathrm{RCT}$ & Yes & 63 & $\begin{array}{l}76 \% \\
(54 / 71)\end{array}$ & $\begin{array}{l}30- \\
50 \mathrm{~W}\end{array}$ & All & $4 \mathrm{~cm}$ & Extractor & $\begin{array}{l}\text { Sacral } \\
\text { block }\end{array}$ & 0 & 0 & 0 & NR & $\begin{array}{l}60.5 \% \\
(43 / 7 \\
1) \\
\end{array}$ & $\begin{array}{l}35.2 \% \\
(25 / 71)\end{array}$ & - \\
\hline \multicolumn{6}{|c|}{ Chen control $n=71$} & & & & & & & & $25.4 \%$ & & & & $77.5 \%$ & & \\
\hline \multicolumn{6}{|c|}{$\begin{array}{l}\text { RoB } \text { : in general = Some concerns; Re recurrence }= \\
\text { Some concerns }\end{array}$} & 62 & $(51 / 71)$ & & & - & & - & $\begin{array}{l}25.4 \% \\
(18 / 71)\end{array}$ & 0 & 0 & NR & $\begin{array}{l}(55 / 7 \\
1)\end{array}$ & $(15 / 71)$ & - \\
\hline \multicolumn{6}{|c|}{ Statistical significance } & NS & NS & & & & & & $<0.001$ & NS & NS & - & - & $\begin{array}{l}\mathrm{p}= \\
0.047\end{array}$ & - \\
\hline $\begin{array}{l}\text { Severgi } \\
\text { na }^{67}\end{array}$ & $\begin{array}{l}2 \\
\text { Wave } \\
- \\
\text { length }\end{array}$ & $\begin{array}{l}201 \\
8\end{array}$ & 34 & Prosp. & No & NR & $\begin{array}{l}82.35 \% \\
(28 / 34)\end{array}$ & $\begin{array}{l}1.94 \mathrm{u} \\
\mathrm{m} \mathrm{Th} \\
1.56 \mathrm{u} \\
\mathrm{m} \mathrm{Erb} \\
1.0 \mathrm{~J} \\
10 \mathrm{~Hz} \\
1.94 \mathrm{u} \\
\mathrm{m} \\
\text { wave- } \\
\text { length }\end{array}$ & NR & NR & NR & NR & NR & NR & NR & NR & NR & NR & $X$ \\
\hline $\mathrm{Tao}^{51}$ & $\begin{array}{l}980 \mathrm{n} \\
\mathrm{m} \\
\text { wave }\end{array}$ & $\begin{array}{l}202 \\
0\end{array}$ & 36 & NR & Yes & UK & UK & UK & UK & UK & UK & UK & $\begin{array}{l}\text { None } \\
(0 / 36)\end{array}$ & $\begin{array}{l}\text { None } \\
(0 / 36)\end{array}$ & UK & UK & UK & UK & UK \\
\hline
\end{tabular}




\section{En bloc TURBT}

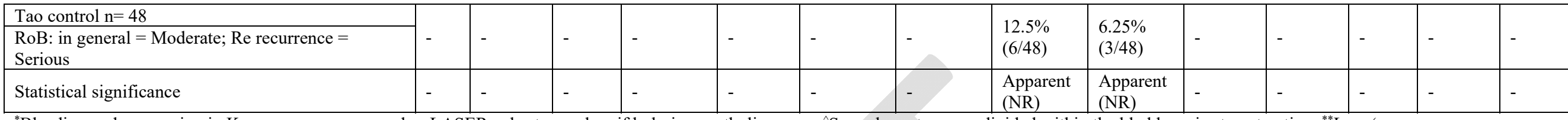

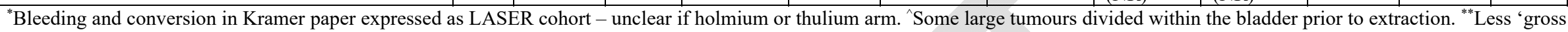

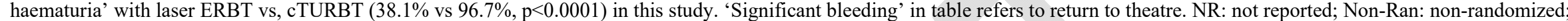
observ: observational; prosp: prospective; RCT: randomized controlled trial; RoB: risk of bias; X: excluded 
CUAJ - Review

Croghan et al

En bloc TURBT

\begin{tabular}{|c|c|c|c|c|c|c|c|c|c|c|c|c|c|c|c|c|c|}
\hline Author & $\mathbf{Y r}$ & $\begin{array}{l}\text { ERB } \\
T^{\wedge} \\
(n)\end{array}$ & $\begin{array}{l}\text { Study } \\
\text { design }\end{array}$ & $\begin{array}{l}\text { Control } \\
\text { group? }\end{array}$ & $\begin{array}{l}\text { Age } \\
\text { (Avg) }\end{array}$ & $\begin{array}{l}\text { Male } \\
\%\end{array}$ & $\begin{array}{l}\text { Feasibil } \\
\text { ity }\end{array}$ & $\begin{array}{l}\text { Max } \\
\text { tumor } \\
\text { Size }\end{array}$ & $\begin{array}{l}\text { Extractio } \\
\text { n }\end{array}$ & $\begin{array}{l}\text { Anesthes } \\
\text { ia }\end{array}$ & $\begin{array}{l}\text { Obturato } \\
\text { r reflex }\end{array}$ & $\begin{array}{l}\text { Bladder } \\
\text { perforati } \\
\text { on }\end{array}$ & $\begin{array}{l}\text { Significant } \\
\text { bleeding* }\end{array}$ & $\begin{array}{l}\text { Muscularis } \\
\text { propria } \\
\text { identified in } \\
\text { specimen? }\end{array}$ & pTa & pT1 & $\geq \mathbf{p T 2}$ \\
\hline${ }_{5}^{\text {Nagele }^{5}}$ & $\begin{array}{l}201 \\
1\end{array}$ & 5 & Prosp. & No & 77 & $\begin{array}{l}80 \% \\
(4 / 5)\end{array}$ & $\begin{array}{l}100 \% \\
(5 / 5)\end{array}$ & $2 \mathrm{~cm}$ & $\begin{array}{l}\text { Endoscop } \\
\text { ic bag }\end{array}$ & NR & NR & $\begin{array}{l}\text { None } \\
(0 / 5)\end{array}$ & $\begin{array}{l}\text { None } \\
(0 / 5)\end{array}$ & $\begin{array}{l}\text { NR } \\
\text { (separate cold } \\
\text { cup muscle } \\
\text { biopsies taken) }\end{array}$ & $\begin{array}{l}100 \% \\
(5 / 5)\end{array}$ & 0 & 0 \\
\hline $\begin{array}{l}\text { Fritsche } \\
56\end{array}$ & $\begin{array}{l}201 \\
1\end{array}$ & 17 & Prosp. & No & NR & NR & $\begin{array}{l}17 / 17 \\
(100 \%) \\
\sim\end{array}$ & $1.6 \mathrm{~cm} \sim$ & $\begin{array}{l}\text { Endoscop } \\
\text { ic bag }\end{array}$ & NR & NR & $\begin{array}{l}\text { None } \\
(0 / 17)\end{array}$ & $\begin{array}{l}\text { None } \\
(0 / 17)\end{array}$ & All & $\begin{array}{l}41.2 \% \\
(7 / 17)\end{array}$ & $\begin{array}{l}29.4 \% \\
(5 / 17)\end{array}$ & $\begin{array}{l}5.9 \% \\
(1 / 17)\end{array}$ \\
\hline Cheng $^{17}$ & $\begin{array}{l}201 \\
8\end{array}$ & 95 & Retro. & $\begin{array}{l}\text { cTURB } \\
\mathrm{T}\end{array}$ & 62.4 & $\begin{array}{l}70.5 \% \\
(67 / 9 \\
5)\end{array}$ & $\begin{array}{l}95 / 95 \\
(100 \%)\end{array}$ & $4 \mathrm{~cm}$ & $\begin{array}{l}\text { Nylon } \\
\text { bag }\end{array}$ & Epidural & $\begin{array}{l}2.1 \% \\
(2 / 95)\end{array}$ & $\begin{array}{l}\text { None } \\
(0 / 95)\end{array}$ & $\begin{array}{l}\text { None } \\
(0 / 95)\end{array}$ & $\begin{array}{l}\text { NR } \\
\text { (separate cold } \\
\text { cup muscle } \\
\text { biopsies taken) }\end{array}$ & $\begin{array}{l}54.7 \% \\
(52 / 9 \\
5)\end{array}$ & $\begin{array}{l}45.3 \% \\
(43 / 9 \\
5)\end{array}$ & 0 \\
\hline \multicolumn{5}{|c|}{ Cheng Control $\mathrm{n}=98$} & \multirow{2}{*}{64.4} & $71.4 \%$ & & & & & $7.14 \%$ & $2 \%$ & None & & $55.1 \%$ & $44.9 \%$ & \multirow[b]{2}{*}{0} \\
\hline \multicolumn{5}{|c|}{ RoB: in general $=$ Moderate; Re recurrence $=$ NA } & & $\begin{array}{l}(70 / 9 \\
8)\end{array}$ & - & - & & - & $(7 / 98)$ & $(2 / 98)$ & $(0 / / 98)$ & NR & $\begin{array}{l}(54 / 9 \\
8)\end{array}$ & $\begin{array}{l}(44 / 9 \\
8) \\
\end{array}$ & \\
\hline \multicolumn{4}{|c|}{ Statistical significance } & - & - & - & - & - & - & - & \multicolumn{3}{|c|}{$\mathrm{P}=0.034$ for complications overall } & - & \multicolumn{2}{|l|}{0.95} & \\
\hline Gakis $^{33}$ & $\begin{array}{l}202 \\
0\end{array}$ & 56 & $\mathrm{RCT}$ & $\begin{array}{l}\text { cTURB } \\
\mathrm{T}\end{array}$ & 66.8 & $\begin{array}{l}80.4 \% \\
(45 / 5 \\
6) \\
\end{array}$ & $\begin{array}{l}\text { All - } \\
\text { exclude } \\
\text { d if not } \\
\end{array}$ & $\frac{\geq}{3 \mathrm{~cm}}$ & Mixed & NR & NR & $\begin{array}{l}1.8 \% \\
(1 / 56)\end{array}$ & $\begin{array}{l}\text { None } \\
(0 / 56)\end{array}$ & $\begin{array}{r}77.4 \% \\
(41 / 56)\end{array}$ & $\begin{array}{l}89.3 \% \\
(50 / 5 \\
6) \\
\end{array}$ & $\begin{array}{l}10.7 \% \\
(6 / 56)\end{array}$ & 0 \\
\hline \multicolumn{5}{|c|}{ Gakis Control $\mathrm{n}=59$} & \multirow[b]{2}{*}{70.2} & $79.7 \%$ & & & & & & & & & $71.2 \%$ & $28.8 \%$ & \\
\hline \multicolumn{5}{|c|}{$\begin{array}{l}\text { RoB: in general }=\text { Low; Re recurrence }=\text { Some } \\
\text { concerns }\end{array}$} & & $\begin{array}{l}(47 / 5 \\
9)\end{array}$ & - & - & Mixed & NR & NR & $\begin{array}{l}1.8 \% \\
(1 / 56)\end{array}$ & $\begin{array}{l}1.1 \% \\
(1 / 59)\end{array}$ & $\begin{array}{r}66 . / \% \\
(36 / 59)\end{array}$ & $\begin{array}{l}(42 / 5 \\
9)\end{array}$ & $\begin{array}{l}(17 / 5 \\
9)\end{array}$ & 0 \\
\hline \multicolumn{4}{|c|}{ Statistical significance } & - & - & - & - & - & - & NR & NR & $\mathrm{p}=1.0$ & $\mathrm{p}=0.49$ & $\mathrm{p}=0.28$ & \multicolumn{2}{|l|}{$\mathrm{P}=0.02$} & - \\
\hline
\end{tabular}

${ }^{\wedge}$ ERBT $\mathrm{n}=$ overall patient number. Multiple tumors were excised in some patients. *Significant bleeding as reported by authors or defined as need for transfusion or manual washout

postoperatively. $\sim 7.5 \mathrm{~cm}$ tumor resected but largest extracted en bloc was $1.6 \mathrm{~cm}$. cTURBT: conventional TURBT (using electrocautery in piecemeal fashion)

NR: not reported; Non-Ran: non-randomized; observ: observational; prosp: prospective; RCT: randomized controlled trial; RoB: risk of bias; X: excluded 


\begin{tabular}{|c|c|c|c|c|c|c|c|c|c|c|c|c|c|c|c|c|c|}
\hline Author & $\mathbf{Y r}$ & $\begin{array}{l}\text { ERBT }^{\wedge} \\
\text { (n) }\end{array}$ & $\begin{array}{l}\text { Study } \\
\text { design }\end{array}$ & $\begin{array}{l}\text { cTURB } \\
\text { T } \\
\text { control } \\
\text { group? }\end{array}$ & $\begin{array}{l}\text { Age } \\
\text { (Avg) }\end{array}$ & $\begin{array}{l}\text { Male } \\
\%\end{array}$ & $\begin{array}{l}\text { Feasibil } \\
\text { ity }\end{array}$ & $\begin{array}{l}\text { Max } \\
\text { tumor } \\
\text { size }\end{array}$ & $\begin{array}{l}\text { Extractio } \\
\text { n }\end{array}$ & $\begin{array}{l}\text { Anesthes } \\
\text { ia }\end{array}$ & $\begin{array}{l}\text { Obtura } \\
\text { tor } \\
\text { reflex }\end{array}$ & $\begin{array}{l}\text { Bladder } \\
\text { perforati } \\
\text { on }\end{array}$ & $\begin{array}{l}\text { Significa } \\
\text { nt } \\
\text { bleeding } \\
*\end{array}$ & $\begin{array}{l}\text { Muscularis } \\
\text { propria identified } \\
\text { in specimen? }\end{array}$ & pTa & pT1 & $\geq \mathrm{pT} 2$ \\
\hline Maurice ${ }^{57}$ & $\begin{array}{l}201 \\
2\end{array}$ & 9 & Retro. & No & NR & NR & $\begin{array}{l}\text { All } \\
\text { (pedunc } \\
\text {-ulated } \\
\text { selected } \\
\text { ) }\end{array}$ & $>5 \mathrm{~cm}$ & $\begin{array}{l}\text { Snare or } \\
\text { endoscopi } \\
\text { c mesh } \\
\text { net }\end{array}$ & $\mathrm{N}$ & $\begin{array}{l}\text { None } \\
(0 / 9)\end{array}$ & $\begin{array}{l}\text { None } \\
(0 / 9)\end{array}$ & 0 & $\begin{array}{l}50 \% \text { polypectomy } \\
\text { specimen } \\
\text { Cold cup biopsy in } \\
\text { addition }->100 \%\end{array}$ & NR & NR & NR \\
\hline Adam $^{58}$ & $\begin{array}{l}201 \\
8\end{array}$ & $\begin{array}{l}4 \\
(18 \\
\text { lesions })\end{array}$ & Prosp. & No & 64.2 & $\begin{array}{l}75 \% \\
(3 / 4)\end{array}$ & $\begin{array}{l}\text { All } \\
\text { selected } \\
\text { lesions }\end{array}$ & $2.6 \mathrm{~cm}$ & $\begin{array}{l}\text { Stone } \\
\text { basket }\end{array}$ & General & NR & $\begin{array}{l}\text { None } \\
(0 / 4)\end{array}$ & 0 & $\begin{array}{l}75 \% \text { polypectomy } \\
\text { specimen } \\
(3 / 4)\end{array}$ & $\begin{array}{l}25 \% \\
(1 / 4)\end{array}$ & $\begin{array}{l}75 \% \\
(3 / 4)\end{array}$ & - \\
\hline $\begin{array}{l}\text { Hayashid } \\
\mathrm{a}^{59}\end{array}$ & $\begin{array}{l}201 \\
9\end{array}$ & 39 & Prosp. & Yes & NR & $\begin{array}{l}61.5 \% \\
(24 / 3 \\
9)\end{array}$ & $\begin{array}{l}\text { All } \\
\text { selected } \\
\text { lesions }\end{array}$ & $6 \mathrm{~cm}$ & NR & NR & NR & $\begin{array}{l}2.56 \% \\
(1 / 39)\end{array}$ & $\begin{array}{l}\text { None } \\
(0 / 39)\end{array}$ & $\begin{array}{l}\text { All with en bloc } \\
\text { base; not specified } \\
\text { for polypectomy } \\
\text { specimen }\end{array}$ & $\begin{array}{l}48.7 \% \\
(19 / 3 \\
9)\end{array}$ & $\begin{array}{l}46.2 \% \\
(18 / 3 \\
9)\end{array}$ & $\begin{array}{l}5.1 \% \\
(2 / 39)\end{array}$ \\
\hline \multicolumn{5}{|c|}{ Hayashida control $n=31$} & \multirow[b]{2}{*}{-} & $67.7 \%$ & & & & & & None & None & All: some cautery & $516 \%$ & $45.2 \%$ & $3.2 \%$ \\
\hline \multicolumn{5}{|c|}{$\begin{array}{l}\text { RoB: in general }=\text { Moderate; } \text { Re recurrence }= \\
\text { Serious }\end{array}$} & & $\begin{array}{l}(21 / 3 \\
1)\end{array}$ & & & & & & $(0 / 21)$ & $(0 / 21)$ & artefact & $\begin{array}{l}(16 / 2 \\
1)\end{array}$ & $\begin{array}{l}(14 / 2 \\
1)\end{array}$ & $(1 / 21)$ \\
\hline \multicolumn{4}{|c|}{ Statistical significance } & - & - & NS & - & & - & - & - & NR & - & - & - & - & - \\
\hline
\end{tabular}

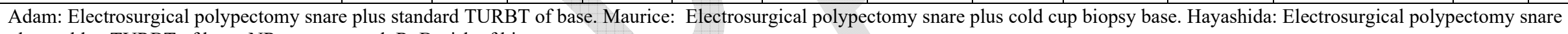
plus en bloc TURBT of base. NR: not reported; RoB: risk of bias 